\title{
Arbitrators Without Powers? Disqualifying Counsel in Arbitral Proceedings
}

\author{
Alan Scott Rau
}

1. The succession of conferences and the proliferation of soft law instruments are always pretty reliable indicators that a particular problem has risen to the level of the consciousness of the international community. That is abundantly true here: They are testimony to a general recognition of the need to identify what limits---if any---there may be to the permissible conduct of counsel in international arbitration, and to identify---always the most interesting question--the appropriate fora in which such questions can be addressed and resolved. ${ }^{1}$

2. My focus here, though, will be on a relatively small piece of the overall puzzle: Rather than to approach globally---from a God's eye view---the problem of sanctions for supposed "counsel misconduct," I want instead to focus on one particular sanction---one that is growing, and promises to grow even more, in importance: the ability of the tribunal to "exclude," or as we say in the States, "disqualify," counsel from the proceedings.

Here is an outline of the argument that follows:
I. The "Power" of Arbitrators to Exclude Counsel: 917 3-11
II. “Conflicts" with Members of the Tribunal: $91712-38$
III. "Conflicts" between Clients: 917 39-42

\footnotetext{
Mark G. \& Judy G. Yudof Chair in Law, University of Texas at Austin School of Law.

This is a much longer version of a presentation made at the $17^{\text {th }}$ Annual IBA Arbitration Day in Paris, on February 14, 2014. "Arbitrators Without Powers?" was the title given to the panel at which I spoke along with Karl-Heinz Böcksteigel, Christine Guerrier, and Gabrielle Kaufmann-Kohler. The privilege of being able to participate with such a very distinguished group of colleagues brought to mind an anecdote told by Boswell about one of his conversations with Samuel Johnson, on the subject of a dinner party they had both attended---in which, as Boswell tells us, "on my observing to him that a certain gentleman had remained silent the whole evening, in the midst of a very brilliant and learned society, 'Sir,' (said he), 'the conversation overflowed, and drowned him."' But I am most grateful for the invitation, for the opportunity to reflect on this challenging subject, and for the good talk involved.

${ }^{1}$ Sounding this theme, inter alia, are Doak Bishop, Ethics in International Arbitration, in ARBITRATION ADVOCACY IN CHANGING TIMES 383, 388 (ICCA $20^{\mathrm{TH}}$ CONGRESS 2010) ("the lack of clarity as to which ethical rules apply, the existence of conflicting rules and obligations, the non-transparency and the increased size of many proceedings, combined with greater public scrutiny, creates a certain instability in the system that could result in a future crisis of confidence"); see also Catherine A. Rogers, Context and Institutional Structure in Attorney Regulation: Constructing an Enforcement Regime for International Arbitration, 39 STAN. J. INT'L L. 1, 2 (2003) ("informal social norms can no longer provide either adequate guidance or control in the face of increasing conflicts"); cf. Charles N. Brower \& Stephan W. Schill, Regulating Counsel Conduct Before International Arbitral Tribunals, in PIETER H.F. BEKKER ET AL. (EDS.), MAKING TRANSNATIONAL LAW WORK IN THE GLOBAL ECONOMY: ESSAYS IN HONOUR OF DETLEV VAGTS 488, 496 (2010).
} 


\section{National Courts and Arbitral Tribunals: 9 TI 43-54 \\ V. Keeping Our Eyes on the Ball: $\$$ II 55-71 \\ VI. Transnational Rules: $9972-77$}

\section{The "Power" of Arbitrators to Exclude Counsel}

Let me start with something that I think is relatively unproblematical and then, as I hope, move on to some things that might possibly be more interesting.

3. It seems apparent to me that the abstract authority----however monitored and controlled---of an arbitral tribunal to "disqualify" the attorney for one of the parties appearing before it, cannot sensibly be challenged. So the text for our discussion instead should be drawn from St. Paul---as he writes in Corinthians, the lesson that "all things are lawful, but not all things are expedient. All things are lawful, but not all things edify." So the question of power is one that is profoundly uninteresting---but, as St. Paul most certainly did not say, "The Devil is in the details."

4. The beginning---and really, I think, the end---of any inquiry into the "power" of arbitrators is to be found in the scope of the consent of the contracting parties--an inquiry into what they have chosen to submit themselves to.

Such a power may be granted to arbitrators through an express submission---or may be granted in the institutional rules that the parties may have voluntarily adopted. (This for example is the effect of the recent revisions to the rules of the $\mathrm{LCIA}){ }^{2}$ Of course a certain hesitancy to go down this path may well be understandable in light of a phenomenon in our world that is all too familiar---that the mere act of providing some explicit source of authority often serves to encourage increased resort to what now benefits from a sort of "green light." (Indeed might disqualification challenges soon become a "mandatory" part of an attorney's arsenal, inherent in his job description, now apparently necessary to demonstrate that he has neglected nothing in the zealous pursuit of the client's interests?) $)^{3}$

\footnotetext{
${ }^{2}$ See the Working Draft [dated February 18, 2014], of the new LCIA Rules 2014, arts. 18.4-18.6 [hereinafter, "LCIA Rules 2-18-14"].

For the power of arbitrators to issue sanctions against attorneys---non parties to the agreement--directly, see $₫ 53$ infra.

${ }^{3}$ This well-understood dynamic may also explain why---despite the interest of certain users, and the overriding values of private autonomy and self-determination---the Arbitration Establishment (in the voice of the AAA) vigorously urged the Supreme Court to invalidate contractual agreements by which parties
} 
5. But in the quasi-inevitable absence of anything explicit, we are led to what I have called a "meta-default rule" that properly informs every feature of our law of arbitration -- I mean, of course, a background rule to the effect that by submitting to the process, the parties in cases of "silence" have presumptively entrusted to their arbitrators a wide-ranging power to determine just how to proceed to resolve the dispute presented to the tribunal. "At the core of any mandate would naturally be matters touching on the appearance of the process and the conduct of the hearings." 4 And the Prime Directive that arbitrators are given is to do whatever it takes to ensure a process that is not only efficient, but both

- decent by community standards and

- in all respects within the legitimate expectations of the parties

consented to judicial review of awards for "errors of law"; see Alan Scott Rau, Fear of Freedom, 17 AMER. REV. INT'L ARB. 469, 505-11 (2006)(tying Ulysses to the mast).

Other illustrations of the phenomenon are abundant. So, for example, the IBA Guidelines on Conflict of Interest may "have provided a well-sprung platform for new tactical challenges to arbitrators" [V.V. Veeder, The English Arbitration Act 1996: Its $10^{\text {th }}$ and future birthdays,

http://www.expertguides.com/default.asp?Page=10\&GuideID=150\&CountrylD=117]--- although it is fair perhaps to refrain from entirely "blam[ing] the messenger," as parties to international arbitration "have taken advantage of the Guidelines" in part because of the same "vexing problem of overly litigious counsel" that arbitrators have faced "since long before the Guidelines came into effect," Leon Trakman, The Impartiality and Independence of Arbitrators Reconsidered, 10(4) INT. ARB. L. REV. 124 (2007). In the present context, cf. Michael E. Schneider, President's Message: Yet another opportunity to waste time and money on procedural skirmishes: The IBA Guidelines on Party Representation, 31 ASA BULL. $3 / 2013$ at p. 497, 500 (2013)(once powers "are spelled out in guidelines and widely publicized, they raise the appetite of litigators and motions for their application risk to become ordinary tools in the proceedings").

${ }^{4}$ Alan Scott Rau, Arbitral Power and the Limits of Contract: The New Trilogy, 22 AMER. REV. INT'L ARB. 435, 473 (2011); see also Oral Argument, Green Tree Financial Corp. v. Bazzle, 2003 WL 1989562 at *25-"26 (U.S.)(Justice Scalia: "they don't consent to every jot and tittle of means by which the arbitration will be conducted; they consent in a gross kind of way to arbitration or nonarbitration, . . . but they don't consent to every consequent detail that enters into the actual conduct of the arbitration").

A number of institutional rules provide a textual hook, an interpretative path towards this conclusion: See generally LCIA Rules 2-18-14 arts. II 14.4, 14.5 (the "general duties" of the tribunal include the duty to "adopt procedures suitable to the circumstances of the arbitration ... . so as to provide a fair, efficient, and expeditious means for the final 'resolution of the parties' dispute," and the tribunal "shall have the widest discretion to discharge" these duties); ICSID CONVENTION, art. 44 ("If any question of procedure arises which is not covered by this Section or the Arbitration Rules or any rules agreed by the parties, the Tribunal shall decide the question").

A simple illustration of the argument: An arbitrator who has been hired to assess the persuasiveness of arguments and proof will naturally tend to discount or devalue assertions that he finds untrustworthy, or evidence whose probative value may be outweighed by the suspicion that it has been obtained inappropriately. Rightly or wrongly, this is merely and precisely what he has been entrusted to do---and so it cannot be thought to "violate the most fundamental notions of due process and fundamental fairness"; but cf. Catherine A. Rogers, supra n. 1 at 55-56 (referring to an arbitrator's distrust of arguments "not adequately rooted in established and applicable legal doctrine" or evidence following "inappropriate pretestimonial communication with a witness"). 
[although these last two may just be different ways of saying the same thing]--including the rights to present a balanced case untainted by unfair advantage, and the right to an impartial award.

This is not attorney discipline; this is not the regulation of the legal profession; this is not "deontology"----a word that I must confess was not even in my vocabulary a few months ago when I was invited to present this paper. It is the simple recognition that---subject to the usual exercise of judicial review---usually benevolent and distracted---it is the arbitrators whom the parties rely on to be the primary guardians of a process in which they are fairly heard and judged. ${ }^{5}$ But that is pretty much where the matter stops. Once we are satisfied with respect to the subject of arbitral power, the only real grounds of disagreement among us are likely to lie in the propriety of the exercise in particular circumstances.

6. And so the elaborate mandatory restrictions spun out by national bar associations and national judiciaries to define what is permissible and impermissible professional behavior---restrictions that codify what conduct the public has a right to expect from practitioners who are not fly by night operators, and who don't cut corners---are in themselves largely irrelevant here: When all is said and done, they are merely the way that established practitioners try to regulate the industry that they are engaged in. Precisely the same phenomenon exists throughout our economy: Plumbers, too--although perhaps not belonging to a "learned profession" as we do---may enjoy a similar monopoly through training and licensing, may engage in similar regulatory control over group members in an attempt to coopt or forestall more direct state regulation---and are equally likely to have their own "Code of Ethics."

When I say that they are "irrelevant,"

- I mean, first and most clearly, that national codes will be irrelevant to the existence of arbitral power.

\footnotetext{
${ }^{5}$ Given this "meta-default rule"---and remembering that we are not talking here about the imposition of disciplinary sanctions against lawyers---I cannot understand why the case for this proposition should be thought to be any stronger in the case of investment-treaty tribunals than in the case of purely "private" commercial tribunals. But cf. Brower \& Schill, supra n.1 at 496 (making such a claim). So, even if it is true to say that "treaty-based arbitral tribunals are not solely consent-based dispute settlement mechanisms"---already a pretty gutsy assertion---I can't see why it should make the least bit of difference. For even "solely consent-based" mechanisms are not limited---no sensible "solely consent-based" mechanism would be limited---to the "explicit conferral of authority by party consent"; id. at 496; cf. Rau, supra n. 4 at $436-475$ (the implications of "silence").
} 
- A second proposition, which doesn't necessarily follow, but which is also true---is that they are largely, if not entirely, irrelevant to the exercise of that power.

I will probably have to qualify that proposition as I go on, but that I think is the essence of the matter. There may not, however, be time or space to indulge in much nuance. Nuance, as she so often does, may have to wait indefinitely. The subject is so rich that I will have to skim lightly over some of the questions raised-this will be, in the terms of the old Chinese proverb,

zou ma guan hua, "glimpsing flowers from horseback"

7. The consequences flowing from a tribunal's action in purporting to remove counsel from participation in a case can be, as we know, draconian: It deprives a party of the sacrosanct "right to counsel of his choice." For in a complex civil litigation or arbitration, a party's attorney "can be just as much an essential part of a properly constituted court as the judge or jury." It is not as if there is ever any particular shortage of adequate substitute counsel eager to take the place of an attorney asked to withdraw. But it must be hard to find a disqualified attorney who has not succumbed to the temptation of believing that he is nevertheless somehow "indispensable." And of course, the resulting dislocation, and delay, and duplication of effort can be immense. ${ }^{7}$

8. The "disqualification" of counsel---if it is not indeed a peculiarly American phenomenon---is rooted---or at least has found its fullest, most elaborate and exotic flowering--- in the practice of American litigation. Occasions in which disqualification has been ordered---or even sought---were relatively infrequent until the 1970's, but have multiplied in abundance since. ${ }^{8}$ In fact the tactical use of attorney-misconduct disqualification motions, as Justice Brennan wrote, is, "a deeply disturbing phenomenon in modern civil litigation.""

9. A natural explanation---and a reasonable starting point---is the traditional authority of a state's judiciary to supervise the local legal profession---to

\footnotetext{
${ }^{6}$ V.V. Veeder, The 2001 Goff Lecture: “The Lawyer's Duty to Arbitrate in Good Faith," 18 ARB. INT'L 431, 446 (2002).

${ }^{7}$ See Richardson-Merrell, Inc. v. Koller, 472 U.S. 424, 441 (1985)(Brennan, J., concurring)("When a trial court mistakenly disqualifies a party's counsel as the result of an abusive disqualification motion, the court in essence permits the party's opponent to dictate his choice of counsel"); see generally Keith Swisher, The Practice and Theory of Lawyer Disqualification, 27 GEO. J. LEGAL ETHICS 1, 64-68 (forthcoming 2013)(“lost money," "lost time," and "lost counsel"; suggesting, however, that these losses are to some extent "speculative" and might often be "mitigated or eliminated").

${ }^{8}$ Kenneth L. Penegar, The Loss of Innocence: A Brief History of Law Firm Disqualification in the Courts, 8 GEO. J. LEGAL ETHIC S 831, 855-56, 889-93 (1995).

${ }^{9}$ Richardson-Merrell, Inc., supra n. 7.
} 
control admission to the bar and the conduct of its members. This is an authority that may actually be written into a state's constitution; ${ }^{10}$ even in the absence of anything so explicit, it is routinely asserted as part of the judiciary's "inherent powers"---"necessary and incidental to the court for its own protection, to secure the proper administration of justice, to maintain the prestige of the profession for integrity, ... and to protect clients from malpractice attended with fraud and corruption." 11 This judicial authority has been the basis for a pervasive regulation of the profession, even in contexts outside the conduct of litigation: It is taken for granted, for example, not only with respect to such matters as admission to the profession and discipline for misconduct, but equally in contexts for which there exist close common-law analogues, such as the policing of the terms of client contracts with respect to the fees that counsel may charge. ${ }^{12}$

And of course the occasions for this judicial exercise of discipline are particularly frequent in the American context: They are multiplied---and the inevitable problems exacerbated---by the constant rubbing, the constant contact with attorney conduct that American litigation affords---for example, in the routine calls made upon a court to monitor pretrial discovery, and, in class litigation, to ensure communications with unnamed members of the class. ${ }^{13}$

\footnotetext{
${ }^{10}$ MONT. CONST. art. VII, § 2(3); see also N.J. CONST. art. VI, § 2, $¥ 3$ (jurisdiction of supreme court "over the admission to the practice of law and the discipline of persons admitted").

${ }^{11}$ State ex rel. McCormick v. Winton, 5 P. 337, 339 (Or. 1884). Almost 200 years ago the U.S. Supreme Court upheld the suspension of an attorney from practice on the ground that "some controlling power, some discretion ought to reside in the Court"; the power is "incidental to all Courts, and is necessary for the preservation of decorum, and the respectability of the profession": And "no other tribunal can decide, in a case of removal from the bar, with the same means of information as the Court itself." Ex parte Burr, 22 U.S. 529 (1824). A fortiori the power must exist not in a case of removal or suspension from practice, but merely from representation in a particular case. See also STEPHEN GILLERS, REGULATION OF THE LEGAL PROFESSION 5 (2009) ("sometimes the court's power is just assumed without a felt need to defend or explain it"); Board of Overseers of the Bar v. Lee, 422 A.2d 998 (Me. 1980) (the "power to define and regulate the practice of law naturally and logically belongs to the judicial department"; the "inherent power" of the supreme court to regulate the conduct of attorneys thus derives from the "concept of separation of powers").

${ }^{12}$ So when a trial court asserts the authority (sometimes on its own initiative) to reduce the fees charged by an attorney in a case before it, it does so not only in its role as an adjudicator of litigated disputes---but in the exercise of its "inherent powers" to supervise the profession.

See generally Alan Scott Rau, Resolving Disputes over Attorneys' Fees: The Role of ADR, 46 S.M.U. L. REV. 2005, 2036-37 (1993); see also Gair v. Peck, 160 N.E.2d 43 (N.Y. 1959) (court has power to adopt a rule setting forth a "schedule of reasonable fees" and method of computation of contingent fees in personal injury and wrongful death cases; the "idea is frivolous that disciplinary power over attorneys is unrelated to the exaction of excessive fees"); American Trial Lawyers Ass'n v. N.J. Supreme Court, 316 A.2d 19 (N.J. 1974) ("[T]he power so vested in the Supreme Court to regulate the practice of the law includes the power to adopt a reasonable rule establishing the outer limits of permissible contingent fees in tort litigation.").

${ }^{13}$ The advent of pre-trial discovery may support in other ways this account of counsel disqualification as a largely American phenomenon: Routine discovery may be responsible for what has been called
} 
10. As a practical matter, as we know, judicial "supervision" to a large extent means "self-regulation through extensive delegation to the organized bar." A state bar association ordinarily functions as an administrative arm of the highest court of the state, for purposes such as assisting in the admission and discipline of attorneys: And so in practice the supervision of the organized bar by the courts is most often exercised "in a passive and reactive capacity." 14

Nevertheless the critical point is that the hierarchical relationship between judiciary and organized bar is taken as a matter of course and uncontested--there is certainly no sense of the bar as representing some separate corporate body, some coordinate regulatory branch, with a pretension to structural independence. How different this is from other models is sometimes hard to grasp: The notion, for example, that the French avocat has traditionally claimed the right to present oral argument without judicial interruption, always evokes a chuckle---of incredulity and doubtless of envy--when it is recounted to American lawyers. ${ }^{15}$

11. Discipline, which is commonly if unthinkingly taken to include the practice of disqualification, has thus been a prerogative exercised regularly by American courts. The power of courts to disqualify counsel has been taken for granted, and judicial disqualification has become the subject of a copious jurisprudence. ${ }^{16}$ Nevertheless:

"churning": That is, in the course of examinations before trial, a number of factual disputes can be expected to disappear, but by the same token others are likely to come to light for the first time---and "no doubt some of the information gleaned through the process of discovery is the awareness by opposing counsel of which lawyers have been involved in some aspect of the adversary's past affairs." In general discovery may have made civil litigation more complex and more protracted, and motions to disqualify opposing counsel have played no small part in contributing to that development. See Penegar, supra $n$. 8 at 887-88.

${ }^{14}$ CHARLES WOLFRAM, MODERN LEGAL ETHICS $33-34$ (1986). In a minority of states, membership in a local bar is not in fact mandatory, and a lawyer discipline agency is instead appointed directly by the state supreme court with the funds provided by a system of registration. But even here, as a matter of practice, "most courts in registration states give the state bar association a strong role in selection of the members for disciplinary agencies [and] in proposing procedural rules." Id. at 38.

${ }^{15}$ See HENRI ADER \& ANDRÉ DAMIEN, RĖGLES DE LA PROFESSION D'AVOCAT $263\left(13^{\text {th }}\right.$ ed. 2010)(the avocat "will not allow himself to be interrupted and, in the interest of the independence guaranteed to the organized bar," should not permit a judge to "talk while he is arguing".) This tradition is apparently an ancient one: See FÉLIX LIOUVILLE, DE LA PROFESSION D'AVOCAT (3d ed. 1864)("the judiciary has the right to our respect," but the Bar "has equally the need to ensure that its independence is respected," and "by independence I mean ... what protects its dignity"---including, among other things, "the absence of questioning [interpellations] and interruptions which are disconcerting for the orator, or disrupt his argument")(quoting Philippe Dupin, Discours de l'ouverture des conférences, Nov. 22, 1834) . Generally on the institutional independence of the French bar from the French judiciary, see JOHN LEUBSDORF, MAN IN HIS ORIGINAL DIGNITY: LEGAL ETHICS IN FRANCE 5-11 (2001).

${ }^{16}$ Compare, as to France, ADER \& DAMIEN, supra n. 15 at 347 ("it is obvious that it is not the role of a judge asked to order interim relief (juge des réferés), no more than that of the court of appeal, to forbid a 
- While the case law is longstanding, elaborate, and (characteristically) highly nuanced, it is not particularly coherent for all that: With respect to challenges alleging a lawyer's conflict of interest, sometimes one reads that with a view to "preventing the appearance of impropriety," doubts . . . should be resolved in favor of disqualification". ${ }^{17}$ Then, at other times one reads that disqualification is "a drastic measure which courts should hesitate to impose except when absolutely necessary"---that because motions to disqualify "impinge on a party's right to employ the counsel of its choice" and have the "strong potential to stall and derail the proceedings," they are "viewed with disfavor" and "reluctance." 18 It is bad enough that courts will regularly be observed to say these different things: It is far worse---unfathomable---to find a single court saying both of these things in the course of a single opinion $!^{19}$

- In addition, the implications of this observation for our present concerns are murky: While superficially one might think that the proposition, "disqualification is a traditional prerogative of the judiciary," would argue for an application---by analogy---to adjudication conducted by arbitrators, this need not in fact follow at all---it has not followed---and the apparent monopoly claimed by the judiciary has posed substantial problems with respect to the extent of arbitral power.

\section{II. "Conflicts" with Members of the Tribunal}

12. So far our discussion of disqualification has been far too abstract----but as Blake said, "To particularize is the alone distinction of merit." 20 So let me do so. We can only approach this subject by taking up separately the very different contexts in which the question of disqualification will arise---the very

lawyer from having as a client the person who chose him"). Cf. Schneider, supra n.3 (commenting that among the possible sanctions for counsel misconduct found in the IBA "Guidelines on Party

Representation," "Guideline 6 even [sic] provides for the possibility of the 'exclusion' of a Party Representative").

${ }^{17}$ E.g., Berg v. Marine Trust Co., N.A., 416 N.W.2d 643, 648 (Wisc. App. 1987).

${ }^{18}$ E.g., First Interregional Advisors Corp. v. Wolff, 956 F. Supp. 480, 489 (S.D.N.Y. 1997); Wyeth v. Abbot Laboratories, 692 F.Supp.2d 453, 457 (D.N.J. 2010),

${ }_{19}$ And with blissful, oblivious, insouciance. See, e.g., Tufamerica, Inc. v. Codigo Music LLC, 2013 WL 1903867 at *3 (S.D.N.Y.)(in the course of a single sentence, "high standard of proof required," "restraint urged before imposing such a drastic measure," "any doubt is to be resolved in favor of disqualification"); Buckley v. Airshield Corp., 908 F. Supp. 99, 304 (D. Md. 1995); In re Cendant Corp. Securities Litigation, 124 F. Supp.2d 235, 249 (D.N.J. 2000); Northwestern Nat'I Ins. Co. v. Insco, Ltd., 2011 WL 4552997 at ${ }^{*} 4{ }^{*} 5$ (S.D.N.Y.)

${ }^{20}$ William Blake, Annotations to Sir Joshua Reynolds' Discourses, in 2 EDWIN JOHN ELLIS \& WILLIAM BUTLER YEATS (EDS.), WORKS OF WILLIAM BLAKE 323 (1893). 
different reasons urged for disqualification---and the different considerations that may be present in each of these various contexts.

13. So, for example, we might begin with the well-known problem of the attempt to disqualify counsel arising out of some relationship he or she may have with a member of the tribunal.

This is the only context in which the question of disqualification is directly addressed in the new IBA Guidelines ${ }^{21}$---a fact that is hardly surprising given that--rare as it is for the subject to actually be adjudicated by international arbitral tribunals---adjudication in other contexts is even rarer. ${ }^{22}$

\footnotetext{
${ }^{21}$ I think this is correct. The reference is to Guidelines 5 and 6 of the IBA Guidelines on Party Representation in International Arbitration (adopted May 25, 2013).

Elsewhere the text of the Guidelines provides a definition of counsel "misconduct" that may sweep rather broadly, defining it to mean "a breach of the present Guidelines or any other conduct that the Arbitral Tribunal determines to be contrary to the duties of a Party Representative." This definition of "misconduct" was presumably inserted to give meaning to Guideline 26 ("Remedies for Misconduct"). And Guideline 26, in turn, authorizes the arbitral tribunal to impose certain sanctions including admonishment, the drawing of adverse inferences, and the allocation of costs---although by telling contrast to Guideline 6, exclusion or disqualification of counsel is not mentioned. Nevertheless it is true that Guideline 26(d) does add a catchall to the effect that the tribunal may "take any other appropriate measure in order to preserve the fairness and integrity of the proceedings." So I suppose, following this route---and at the outer boundaries of a syntactic analysis---the authority for the power to disqualify counsel in all sorts of other situations---other than the Guideline 5 situation of conflict of interest with a member of the tribunal---may be present. This seems a highly roundabout and oblique way of conferring it.

Still, this may provide a textual hook to assure a tribunal that it has some appropriate means of dealing with obstructive behavior in the form, say, of false representations or trivial challenges---conduct that it is now common to refer to as "guerilla" (but not yet "gorilla") tactics. E.g., Stephan Wilske, Arbitration Guerillas at the Gate: Preserving the Civility of Arbitral Proceedings when the Going Gets (Extremely) Tough, in CHRISTIAN KLAUSEGGER ET AL. (EDS.), AUSTRIAN Y.B. ON INT'L ARB. 2011, at 315. Here "disqualification" or "exclusion" would be as close as arbitration can reasonably get to what in the course of ordinary litigation would be sanctioned by courts as "contempt."

In any event, though, whatever "duties" counsel may have within the meaning of the Guidelines do not exist---no "duty" exists---in the ether, and it would be most natural and preferable to view the reference as being to duties owing to the arbitral tribunal rather than to any "ethical" duties of professional responsibility owed to clients; see Comments to Guidelines 1-3 ("an obligation or duty bearing on a Party Representative is an obligation or duty of the represented Party").]

${ }^{22}$ The recent revisions to the Rules of the LCIA are quite similar and similarly cabined, in the sense that they too do not seem to bear on what we usually term the "ethical" duties of professional responsibility owed to clients. An "Annex" to the Rules contains "general guidelines" for counsel conduct, here defining prohibited misconduct in terms considerably more explicit than what is found in the IBA Guidelines--forbidding behavior intended to "obstruct" the process or impair its integrity, such as raising challenges to jurisdiction that are "known to be unfounded," "knowingly" making false statements or relying upon false evidence, "knowingly" "conceal[ing]" documents that the tribunal has ordered produced, or engaging in ex parte communications with the tribunal. Such conduct by counsel may also give rise to the imposition of "sanctions" such as "a written reprimand" or "caution" And here too, there is no actual explicit mention of disqualification---although here too, the tribunal is given the residual catchall power to take "any other measure necessary to maintain [its] general duties"---and in addition the parties are instructed to ensure
} 
14. While the Guidelines speak of "excluding" legal counsel, I note in passing that it is not strictly necessary to characterize the question in precisely these terms in order to deal with the problem addressed in this section. "Framing" here, as everywhere, is critical.

Bear in mind that it is common in arbitral rules to require that the parties at the very outset notify the tribunal, or the administering institution, of the identity of its "party representatives." ${ }^{23}$ Implicit in this, in all probability, is the corollary that any changes or additions to a party's legal staff would presumably also have to be notified to the tribunal. The function served here is primarily one related to good housekeeping.

But it would be a small step, a tweak in the rules, to extend the principle by creating an alternative mechanism that might obviate any need even to talk in terms of "disqualification." This is the effect of an ingenious addition in the recent revision of the LCIA Rules: Under this revision, no change in or addition to a party's legal representation may take effect (at least "in the arbitration") without the approval of the tribunal---and the tribunal may "withhold approval" "where such change or addition could compromise the composition of [the tribunal] or the finality of any award (on the grounds of possible conflict or other like impediment)." In exercising its discretion to grant or withhold permission the tribunal would presumably deploy the cost/benefit analysis suggested---as it is told to consider "all circumstances," including "the efficiency resulting from maintaining the composition of the Arbitral Tribunal as constituted throughout the arbitration." 24

that their legal representations "have agreed to comply" with the guidelines "as a condition" of being able to "appear by name before" the tribunal. LCIA Rules 2-18-14 arts. Iף 18.5, 18.6.

But again, there is certainly no sense that arbitral sanctions are being linked to any external constraints on attorney conduct imposed by codes of professional behavior in the interest of clients; reference to activities that may "jeopardize the finality of any award" [Annex श 2] will simply not bear that weight.

${ }^{23}$ See, e.g.:

- ICSID Arbitration Rules, R.18:

Each party may be represented or assisted by agents, counsel or advocates whose names and authority shall be notified by that party to the Secretary-General, who shall promptly notify the Tribunal and the other party.

- UNCITRAL Arbitration Rules, art. 5:

Each party may be represented or assisted by persons chosen by it. The names and addresses of such persons must be communicated to all parties and to the arbitral tribunal.

See also ICC Rules of Arbitration, arts. 4 \& 5 (necessary information in Request and Answer); IBA Guidelines on Party Representation, supra n. 21, Guideline 4:

Party Representatives [a "Party Representative" is defined elsewhere as "any person ... who appears in an arbitration on behalf of a Party and makes submissions, arguments, or representations to the Arbitral Tribunal on behalf of such Party"] shall identify themselves to the other Party or Parties and the Arbitral Tribunal at the earliest opportunity.

${ }^{24}$ LCIA Rules 2-18-14 arts. II 18.3, 18.4. 
The most important point, though, is this: To start with the proposition that any "change" in representation has to be "approved" calls on a litigant to make its case; the process will inevitably appear far more palatable, far more benign, as an exercise of power than an affirmative and aggressive action of "disqualification"--although in practice, of course, it may amount to much the same thing.

15. It will be no great revelation here to point out that the IBA Guidelines and the new LCIA Rules take as their template the question posed in two ICSID cases--Hrvatska/Slovenia and Rompetrol/Romania ---which are certainly familiar enough to the arbitration community. ${ }^{25}$ The apparent paradigm is the chronological pattern in which those cases unfolded: A tribunal had already been formed, and then one party names additional members to its legal staff. And it would be equally banal to point out that the asserted grounds for "disqualification of counsel" in those cases tracked, or mimicked, the wellknown grounds for which the arbitrators themselves may be challenged for a relationship with litigant or counsel.

16. In Hrvatska the respondent sought "at a very late stage"---two years after the tribunal had been constituted, and only ten days before the first substantive hearing---to add as one of its counsel a barrister who was "affiliated with the same barristers' Chambers" as the President of the Tribunal. The claimant sought an order "that the respondent refrain from using the services" of the barrister in question. And---while it is was conceded that the objection was not predicated on "any actual lack of independence or impartiality" on the part of the President---the tribunal nevertheless found the claimant's objection "well founded"; ${ }^{26}$ it ruled that the barrister "may not participate further as counsel in this case." Note that both parties had "repeatedly affirmed that they did not wish" the President himself to resign, as "the cost and delay implications of that course were apparent to all."27

17. The factual basis for the challenge in Rompetrol seemed considerably weaker. Some time after the tribunal had been constituted, the law firm representing the claimant announced that the case would henceforth be in the hands of a new attorney at the firm who for four years---and until seven months previously---had been a member of the same law firm as the claimant's partyappointed arbitrator. ${ }^{28}$ On the basis of this asserted connection with a member

\footnotetext{
${ }^{25}$ Hrvatska Elektroprivreda, d.d. v. Republic of Slovenia (ICSID Case No. ARB/05/24, May 6, 2008); Rompetrol Group N.V. v. Romania (ICSID Case No. ARB/06/3, Jan. 14, 2010).

${ }^{26}$ Hrvatska at $\uparrow 22$.

${ }^{27}$ Id. at 916.

${ }^{28}$ So the case did not involve the special and rather esoteric problem of barristers' chambers in English legal practice that was central to Hrvatska.
} 
of the tribunal, the respondent moved to disqualify claimant's attorney---but here too, it sought only the disqualification of counsel and did not seek to remove any arbitrator. By contrast with Hrvatska, its motion was denied: The tribunal was willing to "assume" that it did have the power to "control a party's choice of counsel," but stressed that the power could only be exercised in "compelling," "extraordinary" circumstances. ${ }^{29}$ And these were not present here---because no "risk ....genuinely exist[ed]" that the integrity of the tribunal itself would be affected. ${ }^{30}$

18. Neither of these opinions particularly inspires the reader to believe that he has anything approaching a firm grasp of what is going on.

19. The true grounds for disqualification in Hrvatska remain somewhat unclear. To begin with---and this I think is critical---there is the strong suggestion in the tribunal's opinion that

- the standard necessary to exclude counsel is the same standard that would apply if the challenge was made instead to a member of the tribunal---and that

- this standard had been satisfied.

Under the circumstances, said the tribunal, counsel's "continued participation in the proceedings" could only lead a "reasonable independent observer" to "form [a] justifiable doubt" as to the President's "impartiality or independence." And the freedom of the proceedings from such a "justifiable doubt" constituted one of the "fundamental rule of procedure" within the terms of the ICSID Convention. ${ }^{31}$ That the English bar might view such an arrangement with benevolence does not change the fact that the chambers system is "wholly foreign" to parties with a different "cultural perspective." 32

Both cases seem to involve "Orange List" situations; see IBA Guidelines on Conflicts of Interest in International Arbitration (2004), IT 3.3.2 ("members of the same barristers' chambers"), 3.3.3 (within the past three years arbitrator was "affiliated with" "any of the counsel"). But whether the arbitrator in Rompetrol was in fact "affiliated with" challenged counsel might I suppose be doubted given that the latter was apparently only a "salaried employee," with no participation in profits, of the firm in which the arbitrator was a partner. See Rompetrol १ף 6,7; cf. Background Information on the IBA Guidelines on Conflicts of Interest in International Arbitration at p. 435 ("some open norms . . . are unavoidable"). In any event another factor making Rompetrol a weaker case is that there, unlike Hrvatska, the connection between arbitrator and counsel was not simultaneous but had only existed "in the past." Rompetrol, ๆ 26. ${ }^{29}$ Rompetrol, ๆף 15, 16.

${ }^{30}$ Id. ๆๆ 15, 18, 26.

${ }^{31}$ Hrvatska at $\uparrow 30$. This is of course identical to the provisions of the Model Law respecting challenges to arbitrators; see UNCITRAL MODEL LAW, art. 12(2).

${ }^{32}$ Hrvatska at ๆ 30 (adopting the rationale of letters written to the tribunal by claimant), 31 . 
20. Nevertheless it is not at all clear that the simple fact of this connection between counsel and the President of the tribunal would be sufficient---in and of itself---to create a disqualifying "justifiable doubt." 33 So somehow, into this standard of "justifiable apprehension," there entered also a consideration of the respondent's failure to adequately disclose this connection between counsel and President: Among the "relevant circumstances" warranting "justifiable doubt," there had to be included the respondent's "conscious decision not to inform" the tribunal at the time counsel was retained, its tardiness in making the announcement, and its "subsequent insistent refusal to discuss the scope" of his involvement in the case. All this may have been just "errors of judgment," but it created "an atmosphere of apprehension and mistrust which it is important to dispel." ${ }^{34}$

This alternative ground for attack may explain why the claimant, in the course of the preliminary stages of the challenge, "changed its target" from the President of the tribunal to opposing counse $\left.\right|^{35}$---and it is precisely what permitted the tribunal in Rompetrol to attempt to cabin or trivialize Hrvatska by characterizing the disqualification order there as merely "an ad hoc sanction for the failure to make proper disclosure in good time," rather than as a "holding of more general scope."

21. Of course, all this had the effect---and probably the intention---of muddying the waters: The thrust of my argument here has been that the standards for disqualifying counsel and tribunal members should be congruent---that is, that disqualification of counsel is warranted only in the same circumstances that

\footnotetext{
${ }^{33}$ Cf. David J. Branson, An ICSID Tribunal Applies Supranational Legal Norms to Banish Counsel from the Proceeding, 25 ARB. INT'L 615, 619 (2009)(it would be "difficult to fathom" that the tribunal would have found that the President's "mere presence as a door tenant in Essex Court Chambers . . . meant he lacked independence under ICSID rules"); Michael Hwang, Arbitrators and Barristers in the Same Chambers---an Unsuccessful Challenge, 6 BUSINESS L. INT'L 235 (2005)(ICC case very similar in its facts to Hrvatska, but where a challenge was made only to the arbitrator---and only after the close of the evidential hearing; the challenge was dismissed by the ICC Court).

The Hrvatska tribunal itself disclaimed the notion of any "hard-and-fast" rule--- either to the effect that barristers from the same chambers may never act in the same case as counsel and arbitrator---or to the opposite effect, Hrvatska at 931 . Still, the handwriting may be on the wall. See Michael Polkinghorne \& Emilie Gonin, Barristers from the Same Chambers Appearing as Counsel and Arbitrator: Independence Revisited?, 5:2 DISP. RESOL. INT'L 163 (Nov. 2011) ("Without supporting the automatic application of a stricter rule, it appears to the writers that the barristers' 'particularity' will be progressively more difficult to defend"; "it seems clear ... that the enquiry remains fact-based, looking at chambers' membership as one element to consider, unlike law firm membership, which in many jurisdictions seems to be per se fatal"). If by contrast the arbitrator had been a member of a law firm which itself had represented one of the parties, even on unrelated matters, the case for disqualification would become considerably stronger. See generally KAREL DAELE, CHALLENGE AND DISQUALIFICATION OF ARBITRATORS IN INTERNATIONAL ARBITRATION 327-42 (2012).

${ }^{34}$ Hrvatska at $\uparrow 31$.

${ }^{35}$ Branson, supra n. 33 at 617.

${ }^{36}$ Rompetrol at \ 25.
} 
would warrant calling for the arbitrator himself to step down. But what is the effect on this argument of all Hrvatska's emphasis on the claimant's failure to make adequate disclosures?

- It is often said that while there may be certain contested connections with a party that may give rise to a requirement of disclosure by a potential arbitrator, these connections---whatever these may be---are not the same as---are far more extensive than---what would ultimately (following a proper challenge) justify his disqualification. ${ }^{37}$

\footnotetext{
${ }^{37}$ See, e.g., IBA Guidelines on Conflicts of Interest, supra n. 28, "Explanations to General Standard 2 and General Standard 3" ("the test for disqualification should be an objective one," but "a subjective approach for disclosure" is preferable; the two tests "are clearly distinct from each other, and . . .a disclosure shall not automatically lead to disqualification"). The purpose of a required disclosure is merely to set the stage for further dialogue---to "inform the parties of a situation that they may wish to explore further" in order to determine whether a disqualifying conflict is in fact present. See also DAELE, supra n. 33 at 27-28, 24546; JEFF WAINCYMER, PROCEDURE AND EVIDENCE IN INTERNATIONAL ARBITRATION § $5.10 .2(2012)$ (to say that an arbitrator only has a duty to disclose in those limited circumstances "where [he] felt that the grounds for disqualification were made out" is "not the proper interpretation" and not the "preferable articulation of the standard").

The recent English case of A. v. B., [2011] EWHC 2345 (Comm.) would seem to look in the opposite direction. Here a motion to remove a sole arbitrator and set aside a partial award was denied. The arbitrator was a QC who had been retained by counsel for one of the parties to act in a still-active but totally unrelated case. The court noted that while arbitrators "may indeed make wider disclosure out of caution"---while "it may be appropriate in a borderline case to disclose at an early stage"---nevertheless there is only an effective "obligation"---one with legal consequences---"to disclose matters which amount to apparent bias i.e., where [under the common law test] there is a 'real possibility"' that the tribunal itself is biased. A case of non-disclosure "of something which does not amount to apparent bias seems to me a very long way indeed from satisfying the high threshold of serious irregularity" required for vacatur under the English Act. See id. at 9 ๆ 88-90.

Note, however, that $A$. v. B. arose in the very different context of a motion for vacatur: Even if, under the applicable arbitration rules, grounds exist that would warrant the disqualification of a member of the tribunal, an award rendered by that arbitrator would not necessarily justify a court in overturning the award:

- Given the interest in the finality of the awards, it would only be natural if "something more" were necessary for a successful judicial challenge. See Hwang, supra n. 33 at 245-46 (discussing a French case in which the court refused to annul an award where, unbeknownst to the claimant, the respondent's counsel was a barrister from the same chambers as the President of the tribunal; "had the challenge been made at the appointment stage rather than after the award had been rendered," "the principle of finality of arbitral awards would not then be a relevant consideration"); Positive Software Solutions, Inc. v. New Century Mortg. Corp., 476 F.3d 278 ( $5^{\text {th }}$ Cir. 2007)(arbitrator and counsel for one of the parties were 2 of 34 lawyers who had worked together on the same litigation several years previously; vacatur in situations such as this "would seriously jeopardize the finality of arbitration"; before vacatur is warranted, nondisclosure must "create a concrete, not speculative impression of bias."

- This conclusion is reinforced by the presumably exclusive nature of the statutory grounds for vacatur. Cf. Merit Ins. Co. v. Leatherby Ins. Co., 714 F.2d 673 (7th Cir.1983)(“[E]ven if the failure to disclose was a material violation of the ethical standards applicable to arbitration proceedings, it does not follow that the arbitration award may be nullified judicially"; if [a party] is to get the arbitration award set aside it must bring itself within the statute," and "the fact that the AAA went
} 
- And if the duty to disclose is indeed broader---but not honored---what are the consequences of this failure? Here, by the same token, it is often said that the mere fact that a potential arbitrator has not made the mandated disclosures need not necessarily warrant his disqualification. The IBA Guidelines on Conflicts of Interest make this explicit $^{38}$---although suspicion arising from the lack of a requisite disclosure is naturally understandable, and so some slippage is inevitable. ${ }^{39}$

22. But all that learning on the subject of non-disclosure, however interesting, may in the present context amount to little more than esoteric quibbling: What seems far more important---what remains with us in the end---is the quite explicit indication in the Hrvatska opinion that if counsel really cannot be excused, why then, quite simply, it would have to be the President who goes: "The only other realistic outcome" to avoid future problems "would be the resignation of the President"; the presence of counsel "is for all practical purposes incompatible with the maintenance of the Tribunal in its present

beyond the statutory standards in drafting its own code of ethics does not lower the threshold for judicial intervention")..

${ }^{38}$ See IBA Guidelines on Conflicts of Interest, supra n. 28, "Practical Application of the General Standards" I 5 ("non-disclosure cannot make an arbitrator partial or lacking independence; only the facts or circumstances that he or she did not disclose can do so").

${ }^{39}$ See Jeff Waincymer, Reconciling Conflicting Rights in International Arbitration: The Right to Choice of Counsel and the Right to an Independent and Impartial Tribunal, 26 ARB. INT'L 597, 620 (2010) (where the relationship itself "is in a grey area," non-disclosure is at the least a "relevant factor in determining an apprehension of bias"); DAVID D. CARON \& LEE M. CAPLAN, THE UNCITRAL ARBITRATION RULES: A COMMENTARY 226-27 ( $2^{\text {nd }}$ ed. 2012)(a failure to disclose when required by art. 11 "may give rise to, but does not per se establish, justifiable doubts as to impartiality or independence"; the nondisclosure may after all be either "an aberration on the part of a conscientious arbitrator or part of a pattern or circumstances raising doubts as to impartiality"); DAELE, supra n. 33 at 434-440 (collecting authority).

The Revised Uniform Arbitration Act, in force in a handful of American states, imposes a duty on potential arbitrators to disclose a "known, direct, and material interest in the outcome of the arbitration proceeding or a known, existing, and substantial relationship with a party"; failure to do so creates a--presumably rebuttable---presumption of "evident partiality" that mandates vacatur. However, such "interests" and "relationships" are already precisely the same things that under the Act would make the arbitrator ineligible to serve in any event---and so the mere failure to disclose them can't in itself constitute an independent ground for challenge of the award. But in addition, the Act purports to go further--imposing a duty to disclose any "known facts that a reasonable person would consider likely to affect the impartiality of the arbitrator in the arbitration proceeding, including: (1) a financial or personal interest in the outcome of the arbitration proceeding; and (2) an existing or past relationship with any of the parties to the agreement to arbitrate or the arbitration proceeding, their counsel or representatives, a witness, or another arbitrators." Here, if there is a failure to disclose, the court "may" vacate the award [on the ground of the facts themselves? on the ground of the non-disclosure? who knows?]--- but there is no presumption. See Revised Uniform Arbitration Act (2000), § 11 (b) \& cmt. 2; § 12(a), (d), \& (e) \& cmt. 4.

I have no idea what these overlapping provisions could possibly mean, and how this unwieldy machinery could possibly work in operation. But don't get me started on the entirely hopeless and hapless exercise that the Act represents; see Alan Scott Rau, Federal Common Law and Arbitral Power, 8 NEV. L.J. 169, 170-79 (2007)(other examples; "even for this statute, the drafting here is unusually inept."). 
proper composition." 40 This tells us, again, that the exercise of the power to disqualify counsel closely maps upon the power to disqualify members of the tribunal. And if---as appears to be the case---nobody wants to take the latter route, then it may become necessary, for precisely the same reasons, to take the former in its place. On this view, it is not the respondent's non-disclosure itself that is being sanctioned ${ }^{41}$---it is rather the combined effect of

- his tactical behavior, and

- the "atmosphere of apprehension and mistrust"42 which it has created regarding the ability of the tribunal to judge fairly.

Whether through devious calculation, or simple inadvertence, or indeed "error of judgment, ${ }^{43}$ the objective result of respondent's behavior is to bring about a situation in which---at the last possible moment, and with no ready alternative--the parties appear to be left with a tribunal whose legitimacy is "imperiled." 44

23. The Hrvatska decision is nowhere near as flawed as the decision in Rompetrol, which touches all the bases in a way that seems schizophrenic and fundamentally incoherent ${ }^{45}$ :

${ }^{40}$ Hrvatska, ๆף 16, 29.

${ }^{41}$ The Hrvatska tribunal did not rely on the IBA Guidelines on Conflicts of Interest, which in "General Standard 7" impose on a party a duty to inform the tribunal and other parties "about any direct or indirect relationship between it (or another company of the same group of companies) and the arbitrator." Even if this language should be understood as embracing not only the parties themselves but also their counsel--something that is far from certain---there is no suggestion, and it would not be proper to assume, that this provides a textual hook that would justify actual disqualification. In any event note that this language sweeps far more broadly than "General Standard 3" ("Disclosure by the Arbitrator")---the "relationships" it refers to could as easily encompass matters appearing on the "Green List." This then merely serves to supplement the arbitrator's duty of disclosure in circumstances where no blame could possibly attach to the arbitrator himself--- its apparent purpose is not to serve as a red flag signaling possible disqualifying conflicts, but instead on the contrary "to reduce the risk of abuse by unmeritorious challenge."

("Explanation to General Standard 7"). But to the extent that disclosure is relevant to disqualification, I argue, it is solely because of the doubts it may create with respect to the adjudicative legitimacy of the tribunal.

${ }^{42}$ Hrvatska, ๆ 31.

${ }^{43} \mathrm{Id}$.

${ }^{44}$ Id. at $\uparrow 26$.

Until the announcement of the changes in respondent's legal staff, the respondent's delay in disclosure could hardly be attributed to the tribunal itself: Until that time---as long as the tribunal was in ignorance of the possibly disqualifying facts---the respondent's behavior in "lying behind the log" could not possibly "detract from objective perceptions as to the integrity of the tribunal." See Waincymer, supra n. 39 at 612,620 . But the opposite is true, in spades, once the challenged counsel appears at the hearing.

${ }^{45}$ The Tribunal was "not ... convinced that there is any necessary tension between the two basic principles" of arbitral impartiality and the litigant's right to represented by counsel of his own choice. But, it suggested,"if special circumstances were to arise in a specific case such that these two basic principles did come into collision with one another, it would be the tribunal's duty to find a way of bringing them into

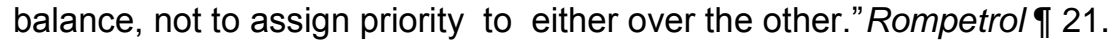


a. There is, first of all, the repeated assurance given us to the effect that the presence of new counsel---formerly employed at the President's law firm--would not seriously affect the neutrality of the tribunal. ${ }^{46}$ This came as a result of applying the standard laid down by the House of Lords---the relevance of which is not immediately apparent until one notes that the Chairman was an English QC---or, alternatively, by the ICSID Convention and Rules. ${ }^{47}$ In any event the contrary was not seriously arguable. ${ }^{48}$ So the matter could rest right there. Is that the "real holding" of the case?

b. At the same time it can't be denied that the opinion breathes skepticism about the propriety of any exercise of the power of disqualification---if power there be---- given

- the lack of textual support in the Convention or Rules, ${ }^{49}$ and

- the possible "human rights" interest of a litigant in being able to retain his counsel of choice. ${ }^{50}$

24. There is thus a good deal of unresolved tension between all these dicta. Still, the lack of textual support is overstated and, of course, as illustrated by the

This is most curious: Conflicts only truly disappear when we can be persuaded that interests which appeared incompatible are, somehow, not in opposition at all. This does tend to happen in the "win/win" hypotheticals beloved of teachers of Mediation---but it is usually far too pat for reality. To "balance" is to weigh, and to weigh is to assign different weights (or greater priority) to different items on the scale. To change the metaphor, when vectors collide the resultant vector---in legal terms, the "result"--reflects the force which has been assigned the greater strength.

${ }^{46} \mathrm{Id}$. at TT 15 (power to be exercised only in "circumstances which genuinely touch on the integrity of the arbitral process as assessed by the Tribunal itself"), 18 (if the "apprehension is one of potential bias on the part of the tribunal leading to a possible advantage to one litigating party," this "might provide grounds for a challenge to the composition of the tribunal"), 26 (tribunal "cannot . . . find anything" that might provide "a reasonable basis .. . for questioning the ability of the Tribunal . . . to judge fairly or exercise independent judgment").

${ }^{48}$ Id. at $\Upsilon 26$.

${ }^{48}$ See DAELE, supra n. 33 at 292-308; see also 1 GARY B. BORN, INTERNATIONAL COMMERCIAL ARBITRATION 1521 (2009)("courts have been reluctant to uphold challenges or annul awards where an arbitrator was not personally involved in representations that were wholly unrelated to the arbitration"). Even the cases discussed in these sources seem somewhat more problematical than the current one---as they involve, for example, past service by the arbitrator as co-counsel with counsel for one of the parties; or past representation of the party in the arbitration by the arbitrator's present law firm. Rompetrol, it will be remembered, involved current representation in the arbitration, but merely by counsel who used to work in the arbitrator's firm.

${ }^{49}$ Rompetrol \ \ 14, 16 ("absent express provisions, the only justification for the tribunal to award itself the power by extrapolation would be an overriding and undeniable need to safeguard the essential integrity of the entire arbitral process"), 19 ("this silence cannot be accidental").

${ }^{50}$ Id. at $\mathbb{2} 20$ ("the European Convention on Human Rights"). 
IBA Guidelines, quickly becomes obsolete. ${ }^{51}$ Point "a." then (the "real holding" of the case) seems preferable as a more authoritative statement.

But if this is the holding, it is certainly accompanied by a most jaundiced attitude: Let us not, the tribunal warns, encourage the idea that challenging counsel is a "handy alternative" to the main event, which would be a challenge "against the tribunal itself"52: While in Hrvatska the fact that the complaining party didn't want to disqualify the Chairman was an element that seemed to leave the tribunal with no choice---poignantly, the very same fact in Rompetrol seemed to make the tribunal uneasy, as bespeaking an unseemly and indelicate tactical maneuvering.

25. Nevertheless, once again, and at the risk of vulgarizing the matter, here is the underlying thread, the fil conducteur, the essence to draw from these decisions: It is that disqualification of counsel must rest on the same basis that---had the argument been made---would justify the disqualification of a member of the tribunal. And this is as it should be, for in either case the gravamen of the complaint is to raise precisely the same doubts about the integrity of the decisionmaking process. ${ }^{53}$

This was said or at least strongly suggested by both tribunals. ${ }^{54}$ The new IBA Guidelines themselves could hardly be more explicit on the subject: They permit "exclusion" of a "new [legal] representative" whenever he or she has a "relationship" with the arbitrator "that would create a conflict of interest"---and we are told that it is the earlier Guidelines on Conflicts of Interests [relating to arbitrators] that we should "rely" on to "assess" this very question. ${ }^{55}$

\footnotetext{
${ }^{51}$ It naturally will take a while to chip away at such failures of the imagination. See also ALAN REDFERN \& MARTIN HUNTER, LAW AND PRACTICE OF INTERNATIONAL COMMECIAL ARBITRATION ๆ 6-20 at fn. 49 (2003), who write that "an arbitral tribunal probably does not have the power to prevent a lawyer from continuing to appear in an arbitration, but a party who does not comply with the reasonable directions of the tribunal risks being held to have waived all or part of the right to be heard"). I can find no trace of this passage in later editions; see NIGEL BLACKABY \& CONSTANTINE PARTASIDES, REDERN AND HUNTER ON INTERNATIONAL ARBITRATION $\left(5^{\text {th }}\right.$ ED. 2009) 9 I $3.227-$ 3.229 ("Ethical Rules"), 6.192 (unless disruptive party conduct has made it "impossible for the arbitral tribunal to conduct the proceedings in an orderly manner," "in principle," "a party may rely on the right to be present, and the right to be accompanied by a representative of his choice, throughout all hearings"). ${ }^{52}$ Rompetrol, $\uparrow 21$.

${ }^{53}$ See Waincymer, supra n. 39 at 617-18 ("the tribunal should approach [the question of challenges to "new" counsel] in the same way [it] would if there was a challenge to the tribunal itself"); see also Peter C. Thomas, Disqualifying Lawyers in Arbitrations: Do the Arbitrators Play Any Proper Role?, 1 AMER. REV. INT'L ARB. 562, 586 (1990)("given the critical role played by lawyers in arbitrations, the potentially damaging effects of their misconduct on the fairness of proceedings may not be all that different from the harm that can result from a biased tribunal," and so "it is difficult to see" why any distinction should be drawn between the two).

${ }^{54}$ See ๆ $22-23$ supra.

55 IBA Guidelines on Party Representation, supra n. 21, Guideline 5, and "Comments to Guidelines 4-6."
} 
26. And so, for this reason:

- The identity of a party's legal advisers (as opposed to his legal representatives)---at least if kept confidential---should pose no problems here, and should give rise to no plausible claim of disqualification. ${ }^{56}$

- And it is perfectly irrelevant that in the practice of the ICJ it is quite common for a state to be represented by counsel "who until recently had been working in close and continuing association with a person who had in the meanwhile been elected to serve as Judge on the Court." ${ }^{\text {57 }}$

In these cases the answer is already embedded in the question, whether in the circumstances a successful challenge could have been mounted to a member of the tribunal itself on the grounds of his doubtful impartiality. (That's the whole point: And the answer is, respectively, no and no). ${ }^{58}$

- By the same token the fact that counsel have "fundamentally different duties" from arbitrators and "are not required to be 'impartial' at all"---indeed are expected to present their party's case "with the degree of dependence and partiality that the role implies"59---is also perfectly irrelevant to the problem we are discussing. We are not after all sanctioning the attorney, but the effect of his conduct on the legitimacy of the tribunal.

27. If the underlying substance is the same---if the challenge to counsel piggybacks upon the possible challenge to the arbitrators themselves---then all we are left with is the standard cost/benefit calculus: That is, one would like to know--given the stage of the proceedings at which the matter arises---which sort of challenge would be less disruptive. In other words, one might ask whether the

\footnotetext{
${ }^{56}$ Hwang, supra n. 33 at 253; see also n. 44 supra. But see UNCITRAL Arbitration Rules, art. 5, supra n. 22 ("such communication [to all parties and to the arbitral tribunal) must specify whether the appointment is being made for purposes of representation or assistance").

${ }^{58}$ Id. at $\uparrow 22$.

${ }^{58} \mathrm{~A}$ judge of the ICJ may only be barred from hearing a case "in which he has previously taken part as agent, counsel, or advocate for one of the parties," Statute of the International Court of Justice art. 17(2). That's a limitation to the judge's own behavior in the same case. In addition, "the Court considers that it is not in the interest of the sound administration of justice that a person sit as judge ad hoc in one case who is also acting or has [within the preceding three years] acted as agent, counsel or advocate in another case before the Court." Practice Direction VII. But that's about it; the matter is perhaps a bit more complicated than that, but not much. See Joseph R. Brubaker, The Judge Who Knew Too Much: Issue Conflicts in International Adjudication, 26 BERKELEY J. OF INT'L L. 111, 116-19 (2008)(should a "publically expressed opinion regarding the preferred outcome of a specific case" be construed as forbidden "advocacy"?)

${ }^{59}$ Rompetrol at 919.
} 
putative gains to adjudicative integrity are better justified by the dislocation to the attorney-client relationship, or by the dislocation to an ongoing proceeding and to the identity of an existing tribunal. The new Rules of the LCIA are phrased explicitly in terms of this calculus: In deciding whether to "withhold approval of any intended change or addition to a party's legal representatives," the tribunal is instructed to "have regard to all circumstances," including:

- "the general principle that a party may be represented by" counsel it has chosen,

- "the stage which the arbitration has reached,"

- the efficiency resulting from maintaining the composition of the Arbitral Tribunal as constituted," and

- "any likely wasted costs or loss of time resulting from such change or addition." 60

Even the apparently prophylactic "Guidelines" of the IBA, if properly used, allow plenty of wiggle room here. 61

28. It is well-understood, and only natural, that challenges to arbitrators become progressively less likely to succeed to the extent that the proceedings are well

${ }^{60}$ LCIA Rules 2-18-14 arts. I 18.4.

The first of these "circumstances"---the "general principle" of the right to choose one's own counsel-will be impaired by definition in any event whenever approval of a party's choice is withheld. To the extent this interest may vary in degree---to the extent, for example, that it may be dependent on the complexity of the case or the expenditure of time and money to date---it is likely already to be largely subsumed by the others. Here perhaps is one illustration: While the challenged attorney in Rompetrol was the new lead counsel for the claimant, the challenged barrister in Hrvatska had been retained to work "principally on matters of quantum"; this would seem to make an order of disqualification less costly and disruptive---the tribunal merely postponed opening statements on quantum matters and proceeded directly to hearing evidence on liability. In short, counsel's presence could be dispensed with given that his presumed utility to the client was outweighed by the presumed harm engendered by the representation. But cf. Waincymer, supra n. 39 at 609 , who suggests that the secondary role of the newly appointed counsel in Hrvatska "might well have pointed in the opposite direction"---although I confess I am not quite able to appreciate the force of this objection.

The "right" of a party to its counsel may also be qualified in this sense: If a tribunal's legitimate concern could be expanded beyond the case before it, to embrace the systemic efficiency of the institution of arbitration, then it might be natural to consider what general deterrence effects are to be gained by discouraging belated and tactical changes in legal representation in the future: Here, and only here, perhaps, might a party's motivations and lack of "good faith" be thought to enter into the "rights" calculus.

As for the others listed "circumstances," they all appear to be different ways of saying pretty much the same thing.

${ }^{61}$ IBA Guidelines on Party Representation, supra n. 21, "Comments to Guidelines 4-6" (the tribunal "may . .. consider" excluding a new legal representative from participating in the proceedings "if compelling circumstances so justify"). 
advanced: $: 22$ At some point it may be overdetermined, then, that if the appointment of new counsel in a contested relationship with a member of the tribunal is deemed illegitimate, it must be the attorney who is banished. Yes, it is often said that decisions with respect to the disqualification of arbitrators should not take into account the "stage of the proceedings" at which the matter is raised---that "the facts and circumstances alone are relevant and not the current stage of the procedure or the consequences of the withdrawal." ${ }^{63}$ To conclude otherwise, it is feared, would only serve to muddle the standard for arbitrator impartiality." ${ }^{64}$ But that's just the point, isn't it? The standard remains precisely the same, although the circumstances may dictate that it is the appropriate remedy that may vary.

29. Even when a U.S. court in the course of litigation is asked merely to disqualify counsel in a case before it, it is not---even when making this limited determination---a stranger to an efficiency analysis: The remedy is not granted as of right but only after a consideration of such factors as the timing of the disclosure or of the challenge, the proximity of trial, and the ready availability of adequate alternative counsel. ${ }^{65}$

${ }^{62}$ See WAINCYMER, supra n. 37 at $\S 10.6$ ("it will often be the case that it may be harder to challenge once the proceedings are on foot simply because the benefits of bringing in a new arbitrator ... need to be weighed against the practical problems of commencing again"). Institutions in particular may be riskaverse and the AAA, for example, "recognizes that [before the hearing has begun] it is preferable and more economical in the long run *** to arrange for the prompt substitution of an arbitrator so that the arbitration can proceed without the threat of subsequent litigation." ALAN SCOTT RAU, PROCESSES OF DISPUTE RESOLUTION ( $4^{\mathrm{TH}}$ ed. 2006)

${ }_{63}$ IBA Guidelines on Conflicts of Interest, supra n. 28, "Explanation to General Standard 3(d)."

${ }^{64}$ See CARON \& CAPLAN, supra n. 39 at 225-26.

${ }^{65}$ E.g., In re Cendant Corp. Securities Litigation, 124 F.Supp.2d 235, 250 (D.N.J. 2000)("even with all parties' agreement that Mr. Wells is a brilliant trial lawyer," "it is not anywhere near the eve of trial," and since the client is also "represented by eminent attorneys" at other firms, it will be "well represented during discovery and at trial"); Beilowitz v. General Motors Corp., 226 F.Supp.2d 565 (D.N.J. 2002)("although this motion was not brought on the eve of trial," the client has been "relying [on counsel's] expertise in the New Jersey Franchise Practices Act and the great resources he has available to him] at his firm; in addition, he has filed a motion for a preliminary injunction that is scheduled to be heard imminently and "it is clear that the prosecution of that motion will be affected and perhaps delayed if [the firm] does not continue to represent him"); Wyeth, supra n. 18 at 458 ("patent cases are more likely to involve intensely complex, specialized issues that require experienced, knowledgeable counsel," and "given Howrey's historical representation," depriving the client of its counsel of choice "deprives [it] of Howrey's depth of experience and expertise".).

Cf. Buckley v. Airshield Corp., 908 F.Supp. 299, 307-08 (D. Md. 1995)("in determining whether a party has brought a motion to disqualify with improper motives," or whether the "motion was delayed for tactical reasons," the timing of the motion becomes an important factor"). The court in Buckley warned nevertheless that it could "not avoid" its "duty and power to regulate the conduct of attorneys practicing before it, in accordance with the Canons," "solely because a party delayed in raising the disqualification issue." However (at least in the absence of any prejudice to the other party in the arbitration) an arbitral tribunal---which should in all circumstances be free of any comparable "duty"--- could certainly do so. 
30. Precisely the same thing should be true in the arbitral context. Here of course there is one important added element: Where contested counsel has been selected following the formation of the tribunal, this behavior may require the decisionmakers to choose between, on the one hand, disqualification of this counsel, and on the other, disqualification of a member of the tribunal itself. ${ }^{66}$ Neither leg (or perhaps neither "horn") of the dilemma is necessarily foreclosed in theory. However rare the former remedy may be in other circumstances--such as cases of obstructive misconduct, or cases presenting a conflict of interests between clients---there is no reason to believe that disqualification in the cases discussed here should ever be deemed "exceptional"; the need for a lawyer is not to be weighed against the impartiality of the tribunal. It seems a fair working presumption, plausible most of the time, that the later appointment of counsel---if it would intentionally or even negligently create a disqualifying conflict with a member of the tribunal---should be impermissible. ${ }^{67}$

${ }^{66}$ It is party choice---either directly or at one remove---that dictates the selection of both counsel and arbitrators, and as a consequence, in both cases, any interference with that choice should be subject to their ex ante expectations. At least in the United States, by contrast, to move that a state or federal judge be recused in the course of litigation on the ground of some relationship with counsel is pretty clearly doomed to be a quixotic exercise; see, e.g., U.S. v. Murphy, 768 F.2d 1518 ( $7^{\text {th }}$ Cir. 1985)(trial judge was close friends with prosecutor, and the two families left on a vacation the day after the defendant was sentenced; "the trip had been planned before the trial," and in fact the judge "advanced the date of sentencing so that he could wrap up [the case] before going on vacation with [the attorney's] family"); Noland v. Noland,, 932 S.W.2d 341 (Ark. 1996)(chancellor who presided over divorce case had previously been represented in personal injury action by counsel who represented wife in pending suit); Aguilar v. Anderson, 855 S.W.2d 799 (Tex. App. 1993)(while counsel's motion for summary judgment was pending, judge successfully telephoned counsel for the purpose of eliciting campaign funds). But see $n$. 65 infra.

${ }^{67}$ Cf. In re FCC, 208 F.3d 137 ( $2^{\text {nd }}$ Cir. 2000)(in connection with a "petition for rehearing," a party retained as "special appellate counsel" the same law firm in which, until very recently, one of the members of the judicial panel had been a member; "tactical abuse becomes possible if a lawyer's appearance can influence the recusal of a judge known to be on a panel"; "as between a judge already assigned to a panel, and a lawyer who thereafter appears in circumstances where the appearance might cause an assigned judge to be recused, the lawyer will go and the judge will stay"; held, court sua sponte directs that the law firm "withdraw its appearance in this matter"; the party "may re-submit its papers within four business days" by another firm.).

A similar cost/benefit analysis would be called for in a more unusual case: Suppose that newlyappointed counsel has some past relationship with the arbitrator---but this time of enmity and hostility, rather than of affiliation---and where the appointment appears to be an attempt to seek tactical advantage by causing the removal of an arbitrator who had been presiding over the case for some time and whose attitude and rulings suggest an unfavorable disposition. See, e.g., Levin v. 40 Fifth Ave. Corp., 2004 WL 5382580 (N.Y. Sup.)(after a lengthy trial, but before a final judgment had been entered, party named a new attorney who in the past, and in the course of representing other clients, had "employed wildly intemperate language falsely accusing the court of judicial corruption, theft, and other crimes"; "it is obvious that [the choice was made because the client believed it] would cause the court to recuse itself from this case"; held, attorney "must be disqualified"). 
31. Remember that in both Hrvatska and Rompetrol, no such choice was called for because any challenge to the arbitrator was explicitly waived. ${ }^{68}$ There may be some cases in which by contrast a choice is necessary, and where disqualification of a member of the tribunal may appear to be the preferable solution. ${ }^{69}$ So this has nothing much to do with any notion of the "immutability" of a tribunal ${ }^{70}$---this is a notion which foreswears the instrumental question ["which course would create the greater dislocation? the greater inconvenience?"] in favor of an priori conceptualism. It is never really necessary to tart up a simple cost/benefit analysis with metaphysics or theology.

32. The links between

- challenges to counsel, and

\footnotetext{
${ }^{68}$ In Hrvatska "neither party wished" the President to resign, see \ 16 supra, Hrvatska, ๆ 31. And so presumably the position of the respondent (the opposing party) was that if it was really and truly necessary for someone to go, then, reluctantly, it should be its own counsel. The parties' ranking of preferences was common and apparent.

In Rompetrol, the party seeking disqualification (the respondent) also did "not, either directly or indirectly, challenge" any arbitrator. The tribunal referred to this as an "election." Rompetrol, $\uparrow 12$. Here, by contrast, the claimant's ranking of preferences (between disqualification of its counsel and disqualification of an arbitrator) was not canvassed---presumably because it was deemed irrelevant. The claimant was not, after all, "challenging" anything at all"; the tribunal would have been highly ill-advised to disqualify one of its members sua sponte. Cf. Shomron v. Fuks, 730 N.Y.S. $2 d 90$ (N.Y. App. Div. 2001)(doubtful of its authority to remove an attorney, the AAA instead removed the arbitrator, but "since neither party objected to [the arbitrator's] continued service, the AAA was not authorized to disqualify him"; thus "the award was invalid"). But surely the claimant's argument to the effect that disqualification of an arbitrator would in fact be less disruptive, and would cause less hardship, should be pertinent---at least once the tribunal manages to muster enough imagination to conceive that it has a choice. And in some cases---even in the absence of any such demonstration---a party with an abnormally strong attachment to its new counsel might be permitted to "buy" the right to retain him---perhaps at the price of expecting him to bear the burden of all the additional costs that will be made necessary by the alternative, that is, by the need to reconstitute the tribunal.

${ }^{69}$ In the typical case our concern will be with the heightened level of trust, credibility, and confidence that an arbitrator will naturally extend, in the course of the proceedings, to the submissions of counsel with whom he has or has had a working relationship; see, e.g., IBA Guidelines on Conflicts of Interest, supra n. 28, Part II: Practical Application of the General Standards, § 2.3.3. Where by contrast the concern arises from a personal relationship of friendship, or consanguinity, between counsel and arbitrator, the problem may run deeper. Cf. id. at $\S 2.3 .8$. Here a successful motion to exclude the former from the proceedings may well give rise to an understandable fear of the latter's continuing resentment and hostility. (I am grateful to Karel Daele for raising this point with me.).

And going beyond the narrow problem of conflicted counsel: Recourse to disqualifying a member of the tribunal would seem inescapable if, for example, a party should name a new CEO who has a close and conflicting relationship with a member of the tribunal; see see Waincymer, supra $\mathrm{n}$. 39 at 611 fn. 37.

${ }^{70}$ Cf. Hrvatska at $\Upsilon$ 27. But even here it was recognized that "immutability was not absolute"---perhaps, for example, an arbitrator may become incapable or unwilling to serve. Id at $\uparrow 28$.
} 
- challenges that are already within the uncontested scope of the power of arbitrators or arbitral institutions---for example, challenges to the composition of the tribunal itself---

are so close as to buttress the argument I made above with respect to arbitral power. Consider, for example, the dilemma of an arbitral institution which has reason to doubt its legal authority to disqualify a lawyer: So, faute de mieux, it goes ahead and disqualifies the arbitrator instead. ${ }^{71}$ It would seem foolish to tie the hands of arbitrators and institutions in this way, restricting their discretion with respect what will make for a more efficient proceeding. ${ }^{72}$ If this discretion is exercised in the interest of maintaining mandated neutrality, it is unlikely to invite a serious or successful challenge to the award later. $^{73}$

33. The argument of the tribunal in Rompetrol includes a rhetorical question of which the author of the opinion seemed poignantly rather proud. (Rhetorical questions are always dangerous devices to play around with.). The tribunal asked, "Does a person acknowledged to have possessed [the requisite] qualifications at the time of appointment ... lose them because from now onwards some or all of the argument presented to him, while still the argument

\footnotetext{
${ }^{71}$ See Shomron, supra $\mathrm{n} 68$. Shomron presents a pattern that is familiar to us by now: After an arbitrator was named, the respondent discharged its attorney and retained a new law firm---and this firm happened to be a client of the accounting firm in which the arbitrator was a retired partner, and for which he continued to perform consulting services. After this was disclosed the claimant objected that "it would be impossible for [a] new arbitrator to take over the case in mid-stream," and so in consequence "it is [respondent's] lawyer who should go and the Arbitrator who should stay." But faced with the respondent's objection that "the AAA had no authority to disqualify a party's attorney," the AAA instead went ahead and removed the arbitrator anyway.

${ }^{72}$ Another illustration of the same point can be found In the Matter of the Arbitration between Erich Borgman Charters Ltd. \& The Oceanic Schools, Inc., 1983 WL 824974 (Society of Maritime Arbitrators). Here one party sought to compel the testimony of his opponent's attorney as a material witness in the arbitration (he had been a "willing and active participant in the transaction"). It was understood that the likely consequence would be his disqualification as counsel from any further participation in the case. Here, as in Shomron, supra n. 68, the opposing party objected that the tribunal "had no authority to decide the qualification or disqualification of an attorney," and just like the AAA in Shromron, the tribunal had doubts on that score. But it had no doubts about its power to determine whether the attorney should be called as a witness---this was "abundantly clear"---and so it ordered his testimony, even though it fully recognized the practical effect this would inevitably have on his ability to carry on with his legal representation of his client.

${ }^{73}$ Indeed, the contrary is more likely: In Shomron, supra n. 68, the court ultimately intervened by overturning the AAA's decision: "Since [as in Hrvatska and Rompetrol] neither party objected to [the arbitrator's] continued service, the AAA was not authorized to disqualify him." The court didn't address the question of the AAA's authority to disqualify the attorney instead---which was hypothetical under the circumstances---but went ahead and proceeded as if this power belonged to the court alone: While "we need not find that [respondent] engaged in arbitrator-shopping," nevertheless the law firm's appearance "tainted the proceeding," and "the most appropriate response to this difficult situation is disqualification" of the law firm."
} 
of the same litigating party, will be delivered through the mouth of a different counsel with whom he has had some form of prior association?"74

Like most rhetorical flights, the hollowness of this becomes evident once one realizes that it could just as easily be turned around---thus: "If an association would be disqualifying, does it cease to be so merely because counsel has only recently been appointed?" And if the answer is no, might there not be fairer and less intrusive ways of dealing with the conflict than by having to reconstitute the tribunal?

34. Nevertheless the tribunal's question does remind us that we really need to be clear as to just what we mean by "disqualification."

35. At these early stages, understandably enough, the decided cases have been a little hesitant about the whole concept. The underlying premise of the question posed in Rompetrol is that

- an order of exclusion would by its nature only regulate "through whose mouth" a party's arguments are made.

- By contrast, however, "the provision of private advice" by counsel on the party's handling of its case, or even counsel's "participation in settling the terms of submissions to be put before the tribunal," could create no "possible risk of bias."

But surely, the tribunal goes on to reason, if both these things are true, then the case for disqualification disappears? For surely there could be "no persuasive logic in admitting that an individual might advise the litigating party, draft its pleadings and submissions, interview the witnesses, and retain the experts---as long as that individual doesn't sign the pleadings or appear to present the argument in person." 75

36. All this reasoning rests on a very narrow premise indeed---a very restrictive view indeed of what should be understood by the notion of "disqualification." And indeed, if that is all there is to it, it becomes a trivial remedy at best---at one and the same time

- contributing only marginal gains to the integrity of the process, and

- causing only marginal disruption to a party's conduct of his case.

\footnotetext{
${ }^{74}$ Rompetrol $\uparrow 18$.
}

${ }^{75}$ Rompetrol $\uparrow 24$. 
37. It is a truism of course that as long as counsel in any of these cases has been operating "behind the scenes"---that is, as long as the tribunal remains ignorant of the possibly disqualifying facts---then the contested relationship alone is unlikely to give rise to any objective doubts with respect to the tribunal's integrity. ${ }^{76}$ But this is not subterfuge; it's just the cutting away of any basis for the challenge in the first place. The rhetoric deployed by the tribunal in Rompetrol simply confuses the question of whether there is an impermissible conflict---the ultimate "justifiable doubt" question---with the issue of the appropriate remedy once such a conflict has surfaced.

If the concern is the possible personal effect on the arbitrator of some affinity with counsel, then once the relationship is known---once the representation has been announced---the remedy obviously has to be broader than just a banishment from oral argument, a ban on face-to-face interaction. In Hrvatska in fact the claimant had originally announced its intention "to ask the Tribunal to recommend to the Respondent that it refrain from using the services of [counsel] at the hearing"77; however, this seems to have been lost sight of---or more probably, abandoned as unworkable---and the final order was far broader---that counsel "may not participate further as counsel in this case." The Romperol tribunal deprecated such an order as being "in strikingly absolute and sweeping terms" --and yet the order seems not only perfectly appropriate but indeed inevitable. An early American case put the matter with refreshing bluntness: A disqualified counsel was "ordered to disappear as counsel for the plaintiff and to disassociate himself from the case."

38. In fact, in most cases where a court has decided to "disqualify" counsel, the result is that the entire law firm is expected to withdraw completely from the representation---the disqualification "radiates" out to disable the firm from accepting the matter, treating those who practice together, no matter how large the firm, as "one lawyer." 80

But this practice of vicarious disqualification takes place in a very different context---that of a challenge based on a conflict of client interests---and is thus a response to the recognition that in such cases, a danger exists that confidential client information may be shared. In Hrvatska and Rompetrol, rather than going down the path of imputed disqualification, might not a better analogy be at hand? Consider the common practice of disqualifying individual counsel when they

\footnotetext{
${ }^{76}$ See n. $44 \&$ text accompanying n. 56 supra.

${ }^{77}$ Hrvatska 910.

${ }^{78}$ Rompetrol 924.

${ }^{79}$ W.E. Bassett Co. v. H.C. Cook Co., 201 F.Supp. 821, 825 (D. Conn. 1962).

${ }^{80}$ GILLERS, supra n. 11 at 140; see also GEOFFREY C. HAZARD, JR. ET AL., THE LAW AND ETHICS OF LAWYERING 473 (4 ${ }^{\text {TH }}$ ED. 2005).
} 
could be called as witnesses in the litigation---in such cases, note, "individual counsel," but not their firms. ${ }^{81}$ Isn't that closer along the line?

- Yes, perhaps, if the only fear is that such a dual role in court, as advocate and witness, might cause "the trier of fact [to] be confused or misled"82--especially in jury trials, where a lay jury may tend erroneously to "accord testimonial weight to [counsel's] closing arguments." ${ }^{83}$ Here at most only the individual's exclusion is warranted. ${ }^{84}$

- No, perhaps, if the fear in such cases as Hrvatska and Rompetrol is that of an "inside track"---of a counsel's supposed familiarity with the predispositions, habits of mind, and thought processes of the arbitrators. Here a possible inequity between the parties arising from asymmetry of information may call for a broader remedy. But such an effect would have to be the result of demonstration rather than amateur speculation. Disqualification for such reasons might well be overinclusive, given that attempts to obtain precisely such insights are already the subject of obsessively thorough investigations into the histories and propensities of potential arbitrators ${ }^{85}$

\section{III. “Conflicts" between Clients}

${ }^{81}$ See ABA Model Rules of Professional Conduct R. 3.7 (b) ("A lawyer may act as advocate in a trial in which another lawyer in the lawyer's firm is likely to be called as a witness unless precluded from doing so [by the general rules with respect to conflict of interest].")

82 Id. cmt. 2.

${ }^{83}$ MacArthur v. Bank of N.Y., 524 F. Supp. 1205, 1208 (S.D.N.Y. 1981)("having seen the attorney take an oath on the witness stand, the jury might accord testimonial weight to his closing arguments"; conversely, "lay observers especially might speculate whether counsel has compromised his integrity on the stand in order to prevail in the litigation").

${ }^{84}$ A jury trial, being the gold standard of uninformed decisionmaking, may need this judicial assistance. But I would think that this argument based on "bafflement arising from confusion of roles" would be far too tenuous to have much purchase---or indeed any purchase at all---in bench trials or in arbitrations before presumably more sophisticated fact-finders; see, e.g., Keoseian v. von Kaulbach, 707 F.Supp. 150,154 (S.D.N.Y. 1989) ("as this matter will not come before a jury, there is no fear, justly invoked where a jury is involved, that the appearance of a lawyer as a witness will confuse lay people").

${ }^{85}$ Cf. Waincymer, supra n. 39 at 612 n.38.

The decision in Hrvatska was made even easier by the claimant's concession that the mere withdrawal of individual counsel (in any event a QC rather than a member of a law firm) "would eliminate the problem entirely." In an aside, the tribunal suggested that the situation might be quite different if instead a party were to "object, on reasonable grounds, that its opponent's' case has been irretrievably infused with decisive strategic contributions from the counsel in question." Hrvatska \ 36 . This may be an oblique reference to the problem I raise in the text, and require a "reasonable demonstration" of insider insight. But it doesn't read that way, and if that's not what it means, I'm not sure I can make much sense of it: Surely the mere appropriation of high-quality lawyering can't be a cause of concern? Surely mere cleverness does not implicate either arbitral integrity or litigant inequality? 
39. In the cases we have been discussing, the presence of counsel was alleged to call into question the very ability of the tribunal to judge impartially---and so a motion for disqualification might be seen as the equivalent or surrogate of--or a marginally less burdensome alternative to---a challenge to the arbitrators themselves.

40. Far more problematical---and doubtful---are cases where the presence of counsel is alleged to amount to a violation of some "ethical" duty owed by counsel to his client---that is, to a form of professional misconduct that in other contexts might give rise to regulatory sanctions. The primary battle ground here is likely to be cases where the attorney is caught in a conflict of representations---a conflict between, on the one hand, the interests of the client he is representing in the arbitration, and on the other, the interests of some other, current or former, client. ${ }^{86}$

41. We are even now seeing disqualification motions based on such grounds and arising in the course of an international arbitration---although as yet this is rare. Such challenges have been made in at least two unpublished arbitration awards---rendered respectively under the auspices of ICSID ${ }^{87}$ and ICC ${ }^{88}$---as well as in some recent proceedings in and around the WTO. ${ }^{89}$

\footnotetext{
${ }^{86}$ See ABA Model Rules of Professional Conduct, R. 1.7 (“Conflict of Interest: Current Clients"), R. 1.9 ("Duties to Former Clients").

After looking at all the published disqualification cases decided in U.S. federal courts between 2003 and 2012, Professor Swisher found that $82 \%$ were based on alleged conflicts of interest, either with former or current clients. Swisher, supra n. 7 at 8.

${ }^{87}$ Decision on Application for Disqualification of Counsel, Fraport AG Frankfurt Airport Services Worldwide v. Republic of the Philippines (ICSID Case No. ARB/03/25, September 18, 2008). See the discussion at $\mathbb{} 56$ et seq. infra.

${ }^{88}$ See Horacio A. Grigera Naón, Choice of Law Problems in International Commercial Arbitration, in [2001] Rec. des Cours 157-61 (discussing Partial Award in ICC case 8879 [unpublished, 1997]). See the discussion at nn. 91, 95, \& 118 infra.

${ }^{89}$ See, e.g., European Communities---Conditions for the Granting of Tariff Preferences to Developing Countries, Report of the Panel, II 7.2-7.17 (WT/DS246/R, Dec. 1, 2003). In this dispute, the EC had questioned whether it was proper for the same counsel [the ACWL] to represent both complaining party India, and third party Paraguay, before a WTO panel. The panel began by claiming that it had "the inherent authority---and indeed the duty---to manage the proceeding" in such a way as to "maintain the integrity of the dispute settlement system." It then noted that "many jurisdictions have elaborated rules of conduct dealing explicitly with conflicts of interest through joint representation." (Understandably--despite the fact that the alleged conflict was based on joint concurrent representation of India and Paraguay---the panel limited itself to considering rules from the U.S., Canada, the EC, and England, jurisdictions where "conflicts of interest" have been the subject of the most sustained and focused inquiry). Among the "common elements" to such rules is "the principle that counsel shall not accept ... representation of more than one client in a matter in which the interests of the clients actually or potentially conflict." But what---properly---proved dispositive here is that India and Paraguay---"the parties most likely to be concerned" by any conflict---had expressly consented to the joint representation; it followed that joint representation was permitted, since the panel was not "faced with an issue of principle or one having systemic implications for the WTO dispute settlement system." Nor had there been any
} 
42. Challenges of this sort may be expected to recur more often in the future--although whether they should be encouraged, is a rather different question: As some of the cases we will be looking at troublingly illustrate, "doing one's duty" as an advocate bleeds readily into a certain officiousness the hallmarks of which are

- A dogged terrier-like alertness to any possible tactical advantage, and

- a steely indifference to any costs or delays that might be imposed by exploiting such advantage, whatever the effects on an efficient procedure.

Bear in mind above all that the purposes and functions served by national rules of professional responsibility are multifold: Whatever their usefulness, they should not unthinkingly be brought to bear in a process of dispute resolution designed for something quite different: Thus regulatory restrictions on attorney behavior need not come into the process of adjudication at all, unless it can be shown that counsel misconduct has affected the fundamental fairness of the proceeding. The line is hard to police, but somebody has to do it.

\section{National Courts and Arbitral Tribunals}

43. A strong current in the American cases is to the effect that this "somebody" must on no account be an arbitrator. (This is in fact probably the "majority rule," although the counting of heads has always struck me as a pretty naïve way of going about what Llewellyn called "the law job."). The prevailing authority is thus to the effect that issues of "disqualification" lie "beyond the

\footnotetext{
"argument or evidence" to indicate that any confidential information, such as written submissions and panel deliberations, had been improperly shared.

Another case arose out of the continuing rivalry between Boeing and Airbus---which also played out, among other venues, in the WTO. Airbus had earlier engaged an attorney to represent it in connection with trade disputes raising issues that were alleged to be "the same as or substantially related to" those in a pending WTO proceeding between the U.S. and the E.C. The attorney later joined a law firm that represented Boeing, and which was named an "outside advisor" to the U.S. in the WTO proceeding. (Although the parties to the proceeding were of course states, both Airbus and Boeing were "stakeholders," and the EC's interests were substantially aligned with those of Airbus). Airbus brought suit to enjoin the law firm from participating in that later WTO proceeding. See Airbus S.A.S. v. Wilmer Cutler Pickering Hale \& Dorr LLP, Amended Complaint, 2006 WL 4753256. The district court stayed the action, suggesting that the matter be presented instead to the WTO; the WTO panel reaffirmed that it "had jurisdiction over the alleged conflict of interest" but dismissed the request as untimely. That was the end of the matter: In later proceedings the U.S. court found that the WTO had been "the appropriate forum" all along. Airbus S.A.S. v. Wilmer Cutler Pickering Hale \& Dorr, LLP, 2007 WL 5084428 (D.C. Super.).
} 
jurisdiction" of arbitral tribunals. ${ }^{90}$ If one tries to unpack the reasons that are given in support, though, one finds at the bottom of the bag nothing but red herrings and irrelevancies and fundamental logical errors:

a. Even if the issue of disqualification is thought to fall within the scope of a valid arbitration clause, it may be said that "public policy" forbids arbitrators from ruling on such matters anyway---as they involve interpretation and application of legally mandatory codes of conduct. ${ }^{91}$ (Sometimes the point is even expressed this way: that arbitrators are forbidden to determine them because they require the application of "substantive state law.") ${ }^{92}$ Such a formulation presumably renders questions of consent, or the provisions of any body of "rules," irrelevant.

b. A related claim is that issues of disqualification must be for the courts alone, because it is the courts alone who are charged with monitoring and supervising the conduct of members of the bar. ${ }^{93}$

\footnotetext{
${ }^{90}$ E.g., Munich Reinsurance America, Inc. v. ACE Property \& Casualty Co., 500 F.Supp.2d 272 (S.D.N.Y. 2007)("the issue before the Pennsylvania court, disqualification of an attorney for an alleged conflict of interest, is a substantive matter for the courts and not arbitrators"). In addition to this, and the cases cited in the notes below, see also R3 Aerospace, Inc. v. Marshall of Cambridge Aerospace Ltd., 927 F.Supp. 121 (S.D.N.Y. 1996)(an action to disqualify counsel brought in state court is not removable to federal court because it is "non-arbitrable" and thus, within the meaning of the New York Convention and the FAA, does not concern "a subject matter capable of settlement by arbitration").

${ }^{91}$ Bidermann Industries Licensing, Inc. v. Avmar N.V., N.Y.L.J., Oct. 26, 1990, at p. 23 (Sup. Ct.)("the regulation of attorneys ... implicate[s] fundamental public interests and policies which should be reserved for the courts and should not be subject to arbitration"), aff'd, 570 N.Y.S. $2 d 33$ (A.D. 1991)(the disqualification issue "is intertwined with overriding public policy considerations" and is thus "beyond the jurisdiction of arbitrators"); Dean Witter Reynolds, Inc. v. Clements, O'Neill, Pierce \& Nickens, L.L.P., 2000 WL 36098499 at *5 (S.D. Tex.)("overarching policy considerations preclude arbitrators, who are often non-lawyers, from interpreting and applying the applicable rules of professional conduct for attorneys").

The same attitude is reflected in an ICC arbitration award of 1997, see n. 88 supra ("even if arguendo the Arbitral Tribunal had concluded that the dispute between Claimant A and counsel for Respondents falls within the scope of the arbitration agreement, it would have found the dispute to be non-arbitrable, since it requires adjudicating on 'the criminal consequences of alleged advocate misconduct"').

${ }_{92}$ Munich Reinsurance America, Inc., supra n. 90 at 275 ("attorney discipline has historically been a matter for judges and not arbitrators because it requires an application of substantive state law regarding the legal profession and results in an enforceable judicial order"); Northwestern Nat'l Ins. Co., supra n. 19 at *5 (same; "arbitrators are selected "primarily for their expertise in the particular industries engaged in and cannot be expected to be familiar with the standards of conduct applicable to the legal profession"). ${ }^{93}$ See Dean Witter Reynolds, Inc., supra n. 91 ("based on the Fifth Circuit's explicit mandate to courts to monitor the ethics of the legal profession"); Munich Reinsurance America, Inc., supra n. 90 at 275 ("'in each state, it is the responsibility of the highest court to dictate standards for . . . discipline of attorneys"; "the tendency to analogize . . . arbitrator to judge, should . . . be avoided"); Bidermann Industries Licensing, Inc., supra n. 91 ("while jurisdiction to discipline an attorney for misconduct is vested exclusively in the Appellate Division, disqualification in a particular matter should be sought in the court in which the motion is pending, or, if no action is pending, at a Special Term of the Supreme Court").
} 
c. Then, it is said, a party could hardly have expected that merely by agreeing to arbitrate, he has "given up its right to seek judicial review of its claims that a former attorney . . . is breaching fiduciary duties owed [him] as a former client." 94

d. And finally, it is asserted that an arbitral tribunal may not pass on ethical breaches by an attorney because the attorney was simply not a party to the underlying arbitration agreement, or to the proceeding. ${ }^{95}$

44. I assume the reader has immediately noticed the many things that are wrong with all this.

\section{5. "Public policy"}

"a." obviously rests on a priori suspicions with respect to the arbitral process that are completely périmées. If the claim is that ethical violations are "inarbitrable" for reasons of "public policy," that boat has sailed; such disputes are no more beyond the presumptive competence of arbitrators than are disputes arising under the antitrust laws. ${ }^{96}$

\section{6. "The exclusive 'supervisory' authority of courts"}

\footnotetext{
${ }^{94}$ Munich Reinsurance America, Inc., supra n. 90 at 275; Croushore v. Buchanan Ingersoll P.C., 1996 WL 932086 (Pa. Com. PI.)(same).

${ }^{95}$ Dean Witter Reynolds, Inc., supra n. 91 at *3-*4 ("arbitration of the present dispute between [the former client] and [the law firm] is not appropriate because [the client] never contracted to arbitrate its disputes against [the law firm]"; "at its core, the disqualification dispute lies between [the client] and [the law firm], not between [the client] and [the other party to the arbitration]"). The ICC award referred to in $\mathrm{n}$. 88 supra makes what I take to be essentially the same point---reminding us, in passing, how closely connected are issues framed in terms of "scope" and issues framed in terms of "the appropriate party": The claims "against counsel for Respondents did not fall within the scope of the arbitration clause [which only concerned] Claimants and Respondents and should rather be the subject of "'domestic proceedings"'). Grigera Naón, supra n. 88 at 158.

${ }^{96}$ Bidermann Industries, supra n. 91, is still curiously the "leading case." Decided in 1991, it relied for its "public policy" rationale on New York cases that declared "inarbitrable" disputes implicating

- $\quad$ state antitrust laws,

- state laws forbidding usurious loans, and

- punitive damage awards in arbitration in violation of state policy.

Even at that date Southland $v$. Keating and Mitsubishi should have indicated to the court that state "public policy" could play no such role in closing off access to arbitration. And since that date, Mastrobuono and Cardegna have only run up the score further, in predictable ways. On Mastrobuono, see Alan Scott Rau, The UNCITRAL Model Law in State and Federal Courts: The Case of "Waiver," 6 AMER. REV. OF INT'L ARB. 223 (1996); on Cardegna, see Alan Scott Rau, Separability, "Illegality," and Federalism: The Cardegna Case in the Supreme Court, MEALEY'S INT'L ARB. REP. (Oct. 2005).
} 
" $b$ " is not, perhaps, totally beside the point: ${ }^{97}$

- The hierarchical relationship---or, perhaps a better metaphor, the "nested" relationship--- that we observe in the U.S. between the state judiciary and the members of the bar, has already been alluded to. This is where the regulation of the legal profession takes place; as "officers of the court," lawyers are responsible to the judiciary for the propriety of their professional activities." ${ }^{\prime \prime}$

- This relationship plays out in all sorts of ways, some of them unexpected. Here's an interesting example: "Mandatory" or "compulsory" arbitration is usually thought anathema to the "contractual," "voluntary" nature of the process. (Indeed in legal systems particularly obsessed with taxonomy, a compulsory process just can't be called "arbitration" at all). ${ }^{99}$ And yet in some U.S. states, by court rule, attorneys are obligated at the request of a client to submit to what looks very much like binding arbitration of any fee dispute between them. ${ }^{100}$ Here, ironically, the values of private justice--imposed now in the service of "regulation of the legal profession"---escape even the preemptive power of the Federal Constitution and its guarantee of a jury trial. ${ }^{101}$

47. The real problem, however, lies elsewhere: It is this: " $b$ " rests on a premise that is both unarticulated and doubtful---a premise that "disqualification is an exercise of---that it should be equated with---professional discipline."

\footnotetext{
${ }^{97}$ Not the least of the "literary offenses of James Fenimore Cooper," in Mark Twain's delightful account, is that the conversations of Cooper's characters "consisted mainly of irrelevancies"---but "with here and there a relevancy, a relevancy with an embarrassed look, as not being able to explain how it got there." The essay is in KENNETH S. LYNN (ED.), THE COMIC TRADITION IN AMERICA 328, 338 (1958). ${ }^{98}$ Florida Ethical and Professional Responsibility Rules for Lawyers and Judges, Ch. 4, Preamble.

${ }^{99}$ Alan Scott Rau, The Culture of American Arbitration and the Lessons of ADR, 40 TEX. INT'L L.J. 449, 478-86 (2005)("to those who possess a more rigorous cast of mind, such a pragmatic--one might even say indiscriminate--application of the notion of arbitration must appear anomalous"). Cf. Charles Jarrosson, Les Frontières de l'Arbitrage, 2001 REV. DE L'ARB. 5, 15, 20-21: Here the a priori assertion is that the arbitrator's authority must have its roots in a voluntary agreement, which is "essential": Although the legislature may have chosen to use the terminology of arbitration, these are not "true arbitrations"; "it's not the cowl that make the monk," and even the state cannot "distort" [dénaturer] the true nature of arbitration by characterizing as arbitration something which it "just isn't."

${ }^{100}$ See Rau, supra n. 12, 46 S.M.U L. REV. at 2032 ("mandatory arbitration may indeed not benefit from the dynamic of self-government that often makes labor and commercial arbitration an extension of the parties' own negotiations," and may "lack the legitimacy of processes founded on consent"; it "is, instead, simply a form of economic or professional regulation").

${ }^{101}$ See $i d$. at 2036-2040 (1993)(“a general right to trial by jury may well be trumped by the judiciary's interest in regulation of the legal profession"; other constitutional objections to mandatory arbitration, such as those founded on the attorney's right to due process of law or equal protection, are properly treated as "frivolous" or "trivial").
} 
The reality is to the contrary, for it is not necessary at all to conceptualize the exclusion of counsel as a disciplinary sanction. The two might well be uncoupled. A corollary then is that the standard for disqualification in an ongoing proceeding need not at all be congruent with the rules of professional responsibility of any organized bar.

48. Here is the time to introduce an important qualification. "Discipline" and "disqualification" are often conflated--- the latter routinely viewed as but a subcategory of the former. ${ }^{102}$ But this is hardly an inevitable way of framing things: Of course we understand that

- regulatory (or if you insist, "ethical") duties imposed on the practice of law, and

- supervision of the adjudicative process (by trial court or arbitral tribunal),

are obviously related. But they are not the same thing. ${ }^{103}$ After all,

- the former is purely an exercise in law-enforcement---responsive above all to externalities such as the interest in both individual and general deterrence of wrongdoing, ${ }^{104}$ and the interest in maintaining public confidence in the legal profession. It envisages the imposition of any number of forms of disciplinary sanctions---retrospective---ranging

\footnotetext{
${ }^{102}$ See James Lindgren, Toward a New Standard of Attorney Disqualification, [1982] AMER. BAR FOUNDATION RES. J. 419, 425 ("courts deciding disqualification motions often see their job as applying or interpreting the [ABA Code of Professional Responsibility]"). For an example, see Talecris Biotherapeutics, Inc. v. Baxter Int'l Inc., 491 F.Supp.2d 510 (D. Del. 2007)("the court has the power to supervise the professional conduct of attorneys appearing before it," and "this includes the power to disqualify an attorney"; the court analyzed the issue of disqualification pursuant to the Model Rules of Professional Conduct, which "the District of Delaware has adopted").

${ }^{103}$ See Lindgren, supra n. 102 at 430 ("a conflict of interest rule that makes sense in discipline may not make sense when an opponent in a lawsuit has an incentive to create a conflict of interest in litigation"), 457 ("many actions that merit a reprimand in discipline are not serious enough to warrant disqualification”); see also Mauritrans GP Inc. v. Pepper, Hamilton \& Scheetz, 602 A.2d 1277, 1285 (Pa. 1992)("a motion for disqualification is simply an injunctive order issued in a case already pending," a "civil proceeding involving legal responsibilities and legal and equitable remedies"; this is not "a disciplinary case").

${ }^{104}$ See, e.g., Fred C. Zacharias, The Purposes of Lawyer Discipline, 45 WILLIAM \& MARY L. REV. 675 (2003)(noting "the varying purposes of discipline," but highlighting the need for

- an inquiry into "the lawyer's qualifications to continue practicing" (as "a follow-up to lawyer licensing"), and

- sanctions that "will best encourage competence and ethical behavior throughout the bar," "seeking to ensure competence throughout the industry").
} 
from reprimands and censure to suspension or disbarment, with which mere dispute settlement need not be concerned. ${ }^{105}$

- The latter, by contrast, is primarily an aspect of the decisionmaker's mandate to resolve disputes---responsive above all to the interest in the proper functioning of the trial process (balancing, for example, concerns of integrity---a fair equality in the presentation of opposing cases---and concerns of efficiency---the minimizing of delay and disruption). Here the interests of the entire legal system outside the hearing room need not be dispositive---need not in fact enter into the matter at all. Another way of saying the same thing is this: An arbitrator who is allowed to exercise this responsibility need not be seen as exercising any "public or punitive functions." 106

- But we can leave aside for the moment any question of possible effects with respect to "third parties": Note that a motion to disqualify counsel is the only sanction for attorney misconduct that affects, not the attorney alone, but the interests of his current client in the ongoing litigation: We know of course that delay, inconvenience, and expense are inevitable if the motion is granted; in addition, a motion to disqualify may affect the dynamics of pending litigation in all sorts of other ways--increasing pressures to settle and creating conflict between attorney and client. ${ }^{107}$ None of this is true in the case of post-hoc disciplinary sanctions. ${ }^{108}$ Indeed, in jurisdictions where a court will entertain a disqualification motion filed directly against an attorney, the client may not even have a chance to be heard and to ask that his interests be taken into account. ${ }^{109}$ But whatever the procedural context: How can

${ }^{105}$ As an "avowedly coercive and public-oriented" mechanism, analogous in many ways to the imposition of criminal sanctions, disciplinary proceedings are subject to many of the same "due process" limitations; see WOLFRAM, supra n. 14 at 99-103, 138 fn. 77 (1986).

${ }^{106}$ Cf. Rogers, supra n. 1 at $52-53$.

${ }^{107}$ See, e.g., Lindgren, supra n. 102 at 432 (while the client "may want to press ahead," "the challenged lawyer may seek a settlement because once the lawsuit has ended, it is unlikely that anyone will pursue the ethical question in disciplinary proceedings"), 433-35 (after disqualification, "the momentum of the case may be affected" in that "the client may lose confidence that he can prove his case in court").

${ }^{108}$ See Nathan M. Crystal, Disqualification of Counsel for Unrelated Matter Conflicts of Interest, 4 GEO. J. LEGAL ETHICS 273, 287 (1990).

${ }_{109}$ E.g., Dean Witter Reynolds, Inc., supra n. 91; Airgas, Inc. v. Cravath, Swaine \& Moore, LLP, 2010 WL 624955 (E.D. Pa.) at * 3 . In neither case was the client a party to the litigation, although a successful claim for injunctive relief would deprive it of the benefit of counsel.

See also Georgian American Alloys, Inc. v. White \& Case LLP, [2014] EWHC 94 (Comm.)(Q.B 2013), IT 3, 87, in which White \& Case was enjoined from acting in the Commercial Court on behalf of a client (a Mr. Pinchuk), because there was "a real risk" that confidential information had come into its possession and that "use of that information (at least inadvertently) has been or will be made in the Commercial Court action." "Mr. Pinchuk was refused permission to be joined as a party" and was "not 
it be thought that the best way to gauge the hardship caused by such delay and inconvenience is to refuse to defer to the tribunal that is in the process of hearing the case?

49. The upshot is that the decision to exclude counsel need not rest on a prior finding that some deontological rule has been violated---and conversely, the decision to exclude need not follow automatically from any such finding. It may be determined that disqualification is not the appropriate, or the least intrusive, remedy----whatever code is thought to be applicable, or however it is read. But conversely---and we have already seen this in earlier sections of this paper ${ }^{110}$---it may be decided that disqualification is warranted, regardless of whether we can point to the violation of any particular code of conduct.

50. There is nothing particularly startling about any of this: The point---that disqualification need not be aligned with a violation of some regulatory rule---is illustrated by the copious jurisprudence that already exists with respect to disqualification in the course of litigation. Note that what I am about to discuss are cases of adjudication conducted by public, state tribunals: But even there we see a growing tendency to "uncouple" discipline and disqualification.

What makes "uncoupling" a bit easier, to begin with, is a contingent structural feature of the U.S. legal landscape: Here "discipline" of attorneys for misconduct under ethical codes is typically reserved for the highest court in the state; a motion to disqualify counsel in a pending action, by contrast, is for the trial judge before whom counsel is appearing. And so a trial judge asked to remove counsel may not see its task as "engaging in discipline" at all---may in fact doubt his authority to do so. ${ }^{111}$ There is instead an increasing tendency to cabin his inquiry to the far narrower question of whether the fairness of this particular proceeding has been affected---in the canonical phrase, whether the attorney's conduct has "disturbed the balance of the presentations" in such a way as to actually "taint the underlying trial."112 The trial judge is not asked to do

permitted to attend the hearing" although "he was allowed to adduce evidence as to the impact on him if the injunction sought were granted").

${ }^{110}$ See II 13-31 supra.

${ }^{111}$ See, e.g., Pantori, Inc. v. Stephenson, 384 So.2d 1357 (1980)("if removal of an attorney is considered to be discipline," then "the trial court had no jurisdiction to remove counsel" because "the supreme court alone has the power to discipline attorneys by the grant of exclusive jurisdiction"; however, "the purpose of the hearing [on a motion to compel withdrawal] is not to determine whether there has been a breach of the Code of Professional Responsibility for which the attorney may be disciplined but whether, because of such breach, one party has an unfair advantage over the other which can only be eliminated by removing the attorney").

${ }^{112}$ E.g., Board of Education of the City of N.Y. v. Nyquist, 590 F.2d 1241 (2 ${ }^{\text {nd }}$ Cir. 1979)(disqualification is ordered most "commonly where the attorney is at least potentially in a position to use privileged information concerning the other side through prior representation, ... thus giving his present client an 
anything more; "the business of the court is to dispose of litigation and not to act as a general overseer of the ethics of those who practice here."113 Such limitations should a fortiori inform our view of the behavior expected of private decisionmakers---for whom the notion of some duty, as public servants, to aggressively advance the wider social interest must seem deeply incoherent.

\section{Finally, considerations like " $b$." alone would in any event map most} unsatisfactorily onto transnational practice. At most---and even then most doubtfully---the "argument from the supervisory power of the state judiciary" might justify a Texas court's disqualifying a lawyer admitted in Texas from appearing for a client in a Texas arbitration. But surely no further: Where is

unfair advantage"; "but in other kinds of cases, we have shown considerable reluctance to disqualify attorneys despite misgivings about the attorney's conduct").

Among the many striking cases exemplifying this principle are In the Matter of the Complaint of Korea Shipping Corp., 621 F.Supp. 164 (D. Alaska 1985)(lawyer met with an executive of the opposing party in the absence of its counsel and discussed pending litigation; "such an ex parte discussion would be a naked violation" of a disciplinary rule and so would "potentially [be] a matter of concern to the grievance committee of the relevant bar association," but it was "not so egregious as to require the intervention of the court"); Richards v. Holsum Bakery, Inc., 2009 WL 3740725 (D. Ariz.)(counsel for plaintiff violated state ethics rules by arranging a meeting with current employees of the defendant; counsel "behaved unethically" and "the public's interest in the scrupulous administration of justice" weighs in favor of disqualification; yet the information counsel obtained "will not substantially and irreparably harm Defendants" and "does not go to the heart of the case"; while potentially a matter of concern to the Arizona Bar, [counsel's conduct] is not so egregious as to require" disqualification); Reese v. Virginia Int'l Terminals, Inc., 894 F. Supp.2d 665 (E.D. Va. 2012)(law firm was concurrently defending a union in an action brought against it by an employee for breach of the duty of fair representation, and also representing the plaintiff in connection with a workers' compensation case; held, the firm has violated the state Rules of Professional Conduct, but "there is nothing to suggest" that the union "has gained an unfair advantage through access to privileged information obtained" through its representation of the employee, and so disqualification is not warranted; "the appropriate sanction is referral" of the attorneys to the State Bar). See also Crystal, supra n. 108 at 287-88 (if counsel misconduct "does not involve a substantial risks of taint to a trial, the use of disqualification as a remedy seems unwise"; goals like "the promotion of public confidence, punishment, and deterrence" can alternatively be served "by either a damage award or disciplinary sanction" against the attorney).

Yes, I am aware that this may not at present constitute the "majority rule." See, e.g., Sullivan County Regional Refuse Disposal Dist. v. Town of Acworth, 686 A.2d 755, 757 (N.H. 1996)("the courts of this State are the primary regulators of attorney conduct," and "it would be inconsistent with this court's supervisory role to relegate the Rules of Professional Conduct to the status of guidelines, to be enforced only when the trial process may be sullied"). But again, I am infinitely less interested in the counting of heads than in doctrinal possibilities---in the scope of available argument---and in particular, in any implications for processes of private justice.

${ }_{113}$ W.T. Grant Co. v. Haines, 531 F.2d 671 ( $2^{\text {nd }}$ Cir. 1976)(allegedly improper communication with a party who had not been represented by counsel; even "if we assume a violation" of the disciplinary rules, it does not follow that disqualification is "appropriate"; "the business of the court is to dispose of litigation and not to act as a general overseer of the ethics of those who practice here unless the questioned behavior taints the trial of the cause before it"; if indeed the firm is guilty of professional misconduct, "the appropriate forum is the Grievance Committee of the bar association."). See also European Community v. RJR Nabisco, Inc., 134 F.Supp.2d 297, 310 (E.D.N.Y. 2001)(trial judge should not be "transformed" "into the Grievance Committee of the bar association which is certainly not his function"). 
the possible connection between the rationale in " $b$." and a judicial order to the effect that a putative "conflict of interest" prevents counsel from Fredonia from appearing in the same arbitration on behalf of a Fredonian client? ${ }^{114}$ That would

- prove highly disruptive to established party expectations----it is, after all, hardly what the choice of a seat is intended to accomplish;

- and in addition---in light of the obsessive attention to "conflicts" learning in American jurisprudence---this would not exactly amount to a talking point in favor of the choice of Texas as an arbitral seat.

\section{2. "The right to seek legal redress for ethical misconduct."}

"c." is a simple non sequitur. For should an arbitral tribunal presume to rule (one way or the other) on a motion for disqualification, its decision could not---in any event---operate as res judicata to bar a subsequent lawsuit for damages brought by the client against the attorney. ${ }^{115}$ Nor, of course, could it foreclose a separate disciplinary action brought by the appropriate authority to punish ethical misconduct (in the highly unlikely events that such misconduct should ever be brought to its attention, and that it should decide to do something about it). ${ }^{116}$ The reason of course is

\footnotetext{
${ }^{114}$ Perhaps our Fredonian counsel, by appearing in a Texas arbitration, is engaged in the prohibited "unauthorized practice of law"? A matter of concern for Texas law indeed, but, fortunately, there is no one who would responsibly make this argument; see BORN, supra n. 48 at 2299-2300 \& $2301 \mathrm{fn} .49$. ${ }^{115}$ See Benasra v. Mitchell Silberberg \& Knupp, LLP, 116 Cal. Rptr. $2^{\text {nd }} 644$ (Cal. App. 2002). The court held that the plaintiff's claim for breach of loyalty against its former attorneys was not foreclosed on res judicata grounds, despite the fact that the plaintiff's previous motion to disqualify had been denied by an arbitral tribunal. We should pause to appreciate here the decision's nice mix of formal and instrumental reasoning: Formally, the two proceedings did not "involve the same claim or cause of action": Since the law firm "was not a party to the arbitration dispute," the plaintiff had had "no real opportunity to assert a claim against" it, and so "the motion to disqualify lacked the most elemental aspect of a claim---an attempt to obtain damages or any other type of relief." The consequentialist argument is more appealing: If a party "knows it may be penalized for initiating a motion to disqualify" in the more informal arbitral setting, by being denied "a later forum in which to fully develop the facts and litigate the issue head on, fewer motions will be made and an opportunity to prevent attorney breaches of duty of loyalty before they occur will be lost."

${ }^{116}$ Cf. David B. Wilkins, Who Should Regulate Lawyers?, 105 HARV. L. REV. 799, 828 (1992)(the "disciplinary system, with its emphasis on ex post review and punitive sanctions, [is] not an effective means of accomplishing the objectives of corporate clients"; therefore "even sophisticated clients" are "unlikely to use the disciplinary system, when they have actually been harmed by lawyer misconduct"); In re American Airlines, Inc., 972 F.2d 605, 611 ( $5^{\text {th }}$ Cir. 1992)("to a very large extent, unless a conflict is addressed by courts upon a motion for disqualification, it may not be addressed at all"; especially in cases of alleged conflicts of interest, "clients and fellow attorneys have little incentive to file formal complaints with disciplinary boards, and the evidence suggests that they in fact do not"). A fortiori with respect to arbitration; as for the arbitral tribunal, it would have to be egregious conduct indeed that would induce
} 
that the violation of public, "ethical" standard was not the subject of any arbitral determination. Since totally different questions are being asked, and different interests pursued, the bugaboo of "duplicative or parallel proceedings" need not detain us.

\section{3. "Attorney is not a party to the arbitral proceeding"}

"d.", finally, is simply absurd: A party to an arbitration who moves for the disqualification of opposing counsel is simply invoking the protection of the tribunal against the other party to the agreement; an arbitrator who considers the motion is merely doing the job---resolving this dispute between two contracting parties---that he was hired to do. ${ }^{117}$ The matter would of course be completely different---the question of counsel consent now critical---should there be any question of imposing financial sanctions or other form of liability directly against the attorney himself. ${ }^{118}$

arbitrators to be sufficiently concerned---or sufficiently officious--- to invoke the law-enforcement mechanism of some unfamiliar foreign jurisdiction. See also BORN, supra n. 48 at 2322 ("in practice," "local bar associations have only rarely sought to impose local standards of professional conduct on locally-admitted lawyers engaged as counsel in international arbitrations."

One highly controversial feature of the recent revisions to the rules of LCIA is the possibility of arbitral sanctions against counsel, not only in the form of "cautions" and "reprimands," but also in the form of "a reference to the legal representative's regulatory and or professional body," LCIA Rules 2-18-14, art. 18.6. But it would have to be egregious conduct indeed that would induce arbitrators to be sufficiently concerned---or sufficiently officious--- to invoke the law-enforcement mechanism of some unfamiliar foreign jurisdiction.

The desire to maintain the privacy and confidentiality of the arbitration process will further militate against disclosure. (I imagine though that where bar rules impose on the lawyer-arbitrator a professional duty to report misconduct, the interest in confidentiality would presumably have to yield; see Rau, supra n. 12 at 2046 fn. 146; but see Steven C. Bennett, "Who is Responsible for Ethical Behavior by Counsel in Arbitration," 63-JUL DISP. RESOL. J. at 1, 6 (2008)("there is relatively limited guidance" on this issue). In general, see WOLFRAM, supra n. 14 at 683 ("probably no other professional requirement is as widely ignored by lawyers subject to it" as is the "mandatory reporting obligation on every lawyer with respect to others lawyers' violations of the professional rules").

117 See Canaan Ventures Partners, L.P. v. Salzman, 1996 WL 62658 (Conn. Super.)(defendant argues "that the dispute is between Salzman and [the law firm of] Cahill [Gordon]," but in reality "the dispute is between Salzman and Canaan [the two parties to the arbitration] relating to Canaan's choice of counsel to represent it").

${ }^{118}$ See InterChem Asia 2000 Pte. Ltd. v. Oceana Petrochemicals AG, 373 F.Supp.2d 340 (S.D.N.Y. 2005 )(an award of attorney's fees in the amount of $\$ 70,000$ was rendered against counsel personally because of his "peculiar and extremely harmful dealing with documents in this case"; held, this award "exceeded the arbitrator's authority"; "granting the arbitrator authority beyond that granted to him by the parties conflicts with the most basic principles underlying the arbitration process"); CBC Oppenheimer Corp. v. Friedman, 2002 WL 244820 (Cal. App.)(arbitrators held that claimant and its attorney were "jointly and severally liable" in the amount of $\$ 700,000$ "for the filing of a frivolous claim for which there was no factual foundation"; held, award against attorney vacated; his "representation of the claimants at the arbitration cannot be construed as his agreement to become a party to the arbitration agreement"); MCR of America, Inc. v. Greene, 811 A.2d 331 (Md. App. 2002) (arbitrator had no authority to assess fees against counsel personally despite finding that he had been "obstructive, uncivil, pedantic [!], 


\section{The cases that take this position are not content merely to reserve the} possibility of a court's later "second look" at an arbitral order with respect to disqualification. Instead many go further---and refuse to allow the arbitration to proceed at all until the court itself has resolved the issue. ${ }^{119}$ An injunction may indeed be the logical corollary of the finding of "inarbitrability," ${ }^{20}$ but it reinforces even further our concern about the general premise:

disrespectful of witnesses and his colleagues at the bar, and disparaging of the process of arbitration," and that "his redundant objections ... a and his vexatious pattern of examination of witnesses wasted considerable time and multiplied the costs of these proceedings"; "we are not inclined to accept a broadening of the powers of an arbitrator while our authority to review the exercise of those powers remains narrow").

To the contrary, though, is an occasional outlying case and a good deal of well-intentioned but shallow commentary. E.g., Bak v. MCL Financial Group, Inc., 88 Cal. Rptr. 3d 800 (Cal. App. 2009)(arbitrator ordered attorney to pay $\$ 7500$ as a sanction for the copying of privileged documents; "by voluntarily appearing for defendants in the arbitration proceedings, which included conducting prehearing discovery," counsel "subjected himself to the jurisdiction of the arbitration panel and was subject to its rulings"). See also Bennett, supra n. 116 at p. 4, who argues that "counsel's participation in arbitration" "arguably constitutes consent of counsel" to be bound by the results of the arbitration, citing in support cases dealing with the question of "binding nonsignatories to arbitrate." Wilske, supra n. 21 at 328-29, makes the same move based on "consent through participation in the arbitration," and adds the truly mystifying argument that the tribunal should have the power to impose monetary sanctions "as counsel of record is certainly no stranger to the arbitration and is sometimes even addressed by arbitration rules."

It should be obvious that all of this evidences considerable conceptual confusion, hopelessly muddling:

- the notion of duties which are necessarily based on contractual consent, and

- the notion of duties which arise out of the role of an agent or representative.

The former is pretty reliably a fatal stumbling block to attempts to bind non-parties to the agreement, in the absence of something like ratification or estoppel. The latter is perfectly consistent with the ability of any tribunal to hold a principal liable for the misconduct of its agent, for example, where a contractual obligation of confidentiality has been breached; cf. Wilske at $329 \mathrm{fn}$. 68 . But there is nothing in respondeat superior that binds an agent to obligations undertaken by his principal.

A better, if perhaps excessively charitable, view is found in BORN, supra n. 48 at $2320 \mathrm{fn} .139$ ("Although counsel's participation in the arbitral proceedings or submissions to the arbitral tribunal might arguably give rise to some sort of limited arbitration agreement, this analysis is artificial and would produce anomalous results").

The ICC award referred to in $\mathrm{n} .88$ trots out the argument that even disqualification should be beyond the powers of an arbitral tribunal because it would "damage the interests" of counsel who is not a party to the agreement. Of course, disqualification may indeed be (at worst) "embarrassing." See Thomas, supra n. 53 at 575 . But I doubt that this alone should weigh very heavily in the balance, against a focused exercise of arbitral authority deployed in the interest of preserving a fair proceeding---especially if counsel is entitled to be heard in opposition to any motion that raises his misconduct as a reason for excluding him.

${ }^{119}$ E.g., Bidermann Industries Licensing, Inc., supra n. 91 (staying arbitration of the issue of lawyer disqualification); Munich Reinsurance America, Inc., supra n. 90 (declining to appoint umpire in order to move arbitration forward "pending a decision from the Pennsylvania court on [claimant's] motion for disqualification"); Croushore, supra n. 94 ("the arbitration proceedings cannot go forward until the disqualification claim based on the alleged breach of a fiduciary duty is resolved," and "disqualification is a matter that can be promptly resolved through judicial proceedings" under local rules).

${ }_{120}$ Alan Scott Rau, Understanding (and Misunderstanding) "Primary Jurisdiction," 21 AMER. REV. INT'L ARB. 47, 114-19 (2010). 
a. As we have seen, questions of disqualification of counsel are often closely linked to questions that go to the suitability of the tribunal itself. $^{121}$ In both cases, the timing of challenges is critical---and precisely the same concerns with respect to judicial intervention in midstream, counselling against interlocutory challenges in the latter case, apply here. National rules do differ as to the appropriateness of early challenges to arbitrators---but at least in the U.S. the understanding is that the matter must wait until an award has been rendered. ${ }^{122}$ In both cases the interest in allowing the arbitration to

${ }^{121}$ See ๆी 27-33 supra. A poignant illustration of how these challenges may be interconnected is provided by Northwestern Nat'l Ins. Co., supra n. 19. Here respondent's party-appointed arbitrator---claiming to be concerned about the lack of neutrality of other members of the tribunal---shared private email communications among tribunal members with respondent's counsel. When this was discovered, the arbitrator resigned. The claimant filed a petition to have the court name a replacement arbitrator; at the pre-motion conference the respondent, relying on these communications, announced that it intended to file a motion to challenge the remaining members of the tribunal---but it did not file the motion "after being told by the Court that it could not entertain an attack upon the qualifications of the arbitrators until after the conclusion of the arbitration." So a few months later, the claimant duly moved to have respondent's counsel disqualified, and the court agreed that immediate disqualification was warranted: Counsel's conduct "was a serious violation of arbitral guidelines, as well as ethical rules," and "has a strong tendency to taint arbitral proceedings."

122 E.g., Gulf Guaranty Life Ins. Co. v. Conn. Gen. Life Ins. Co., 304 F.3d 476 (5 $5^{\text {th }}$ Cir. 2002)(defendant filed a motion to strike its opponent's chosen arbitrator on the ground that he did not meet the "qualifications"---that arbitrators be "executives of a life insurance company"---required by the agreement; held, the dispute, "although framed as a request to the court to enforce the arbitration agreement by its terms, is not the type of challenge that the district court was authorized to adjudicate pursuant to the FAA prior to issuance of an arbitral award"; "even where arbitrator bias is at issue, the FAA does not provide for removal of an arbitrator from service prior to an award, but only for potential vacatur of any award"). See BORN, supra n. 48 at $1562-69$ (U.S. is "almost unique" in this reluctance to admit interlocutory challenges).

Of course even in the U.S. the matter becomes murkier if one wishes to dig a little deeper. Gulf Guaranty Life adequately recites the "black letter law." But nevertheless:

- The very existence of a binding agreement to arbitrate can be questioned at any time; U.S. procedure "has been exceptionally generous in providing an abundance of devices through which challenges to arbitral authority may be raised," making a judicial determination possible not only on review of an award, "but also before any proceedings at all have commenced, by a motion to stay litigation or to compel arbitration," Rau, supra n. 120, 21 AMER. REV. INT'L ARB. at 115-16 . So this notion will certainly embrace challenges to an arbitral tribunal that has been allegedly structured by the agreement in such a way as to render it "unconscionable" under the law of Contracts. E.g., Graham v. Scissor-Tail, Inc., 623 P.2d 165 fn. 1(Cal.1981)(vacating order compelling arbitration; the arbitration clause is "unconscionable and unenforceable" because "it designates an arbitrator who, by reason of its status and identity, is presumptively biased in favor of one party"). For a different rationale but reaching the same result, cf. Hooters of America, Inc. v. Phillips, 173 F.3d 933 ( $4^{\text {th }}$ Cir. 1999)(arbitration rules provided that arbitrators must be selected from a list created by the employer and gave employer "control over the entire panel"; held, trial court's refusal to compel arbitration affirmed; "because Hooters set up a dispute resolution process utterly lacking in the rudiments of even-handedness, we hold that Hooters breached its agreement to arbitrate"). 
proceed unimpeded, and in discouraging the "sideshow" of satellite litigation, should be privileged.

b. Any arbitral decision with respect to disqualification will not, as I said, have any res judicata effect in a later separate action against counsel. But note that this possibility of a "second look" does not at all affect the finality to be accorded to the award itself. Whatever the merits of the claim of professional misconduct, and wherever it should ultimately be resolved, it is highly unlikely that it could be shown to have so infected the award, to have had such an impact on the result, as to be a ground for vacatur. ${ }^{123}$

- In addition, I suspect that one of these days, members of the state bars of Texas, or California, or Florida, will begin to explore the implications of the verbatim adoption in those states of the UNCITRAL Model Law: For example, perhaps they will eventually seize on the Law's mechanism for interlocutory challenges to arbitrators in international cases----and take it as an invitation, something which might be exploited once the compatibility of art. 13 (3) with federal law is settled. See CAL. CODE CIV. PRO. § 1297.134; TEX. CIV. PRAC. \& REM. CODE § 172.660; FLA. STAT. § 684.0014(3). Rau, supra n. 39, 8 NEV. L.J. at. 179 ("aping our betters"; "the local boosterism, the poignant self-aggrandizement that has led to the adoption in a number of [U.S.] jurisdictions of the UNCITRAL Model Law").

On these and other possibilities, see the excellent note by Yulia Andreeva, How Challenging is the Challenge, or Can U.S. Courts Remove Arbitrators before an Arbitration Has Come to an End?, 19 AMER. REV. INT'L ARB. 127 (2008).

${ }^{123}$ In Pour le Bébé v. Guess? Inc., 5 Cal. Rptr. 3d 442 (Cal. App. 2004), the respondent sought to disqualify the claimant's counsel on the ground that its past representation of the respondent "had resulted in disclosure of confidential information substantially related to the issues raised in the arbitration." The arbitrators denied the motion, and rendered an award for the claimant. On a motion to vacate, the court touched all of the bases:

- There was "at least a colorable claim" that the opposing party's counsel had engaged in "conflicted representation" in violation of the Rules of Professional Conduct.

- And the arbitrators' ruling on that subject was not free from collateral attack, so that a court could review it. [This is in fact the same litigation as Benasra, supra n. 114, where the point had already been decided].

- But---and critically---the award had not been "procured by corruption, fraud, or undue means" within the meaning of $\S 10(a)(1)$ of the FAA. The FAA requires a showing that the "undue means caused the award to be given,"---that is, that it "affected the outcome of the proceeding"--- and the claimant failed to "highlight [any] aspect of the [award] that might have been impacted by any confidential information allegedly obtained [by counsel] in the course of its representation of [respondent]: Since under U.S. law arbitrators are not even required to explain the reasons for their awards, "we presume [they] took a permissible route to the award where one exists."

As this illustrates, the finality of the award will of course be dependent upon the law of the seat--but this is pretty much the only way in which the law of the seat becomes relevant.

Even more quixotic are attempts to resist enforcement of an award on the ground that unbeknownst to the losing party, its own counsel was conflicted. See, e.g., 1199 SEIU Healthcare Workers East v. Lily Pond Nursing Home, 2008 WL 4443945 (S.D.N.Y.)(defendant's former attorneys had "conflicts of interest that offended New York's Code of Professional Responsibility," but defendant had "failed to demonstrate that the conflicts affected the arbitration proceedings in any way"; "for better or for worse, parties are generally bound by the acts of their freely chosen lawyer-agents"); Fitzroy Engineering, Ltd. v. Flame Engineering, Inc., 1994 WL 700173 (N.D. III.)(respondent challenged a foreign award on the 
c. An injunction against representation might perhaps be justified where it appears the matter will not be addressed in an alternative forum: But things are totally different where it can. ${ }^{124}$ Assume there is a question of enjoining legal representation in pending litigation in another jurisdiction---thereby preempting any contrary decision elsewhere. Courts that refuse to intervene in such cases quite properly point out that:

- The local tribunal, more familiar with the facts and more alert to the dangers of disruption of an ongoing proceeding, will be best situated to deal with the question, that

- it alone can shape discovery and the presentation of evidence in response to any putative breach of ethical duties, and that it alone can accurately assess objections to a challenge founded on delay or "waiver," and in any event that

- piecemeal litigation can hardly be conducive to the "efficient administration of justice." 125

Considerations of at least the same force should apply where the "alternative forum" is an arbitral tribunal. ${ }^{126}$ Granted, there may perhaps be

ground that its attorney had been representing another company which was the end user and operator of equipment it had agreed to provide, and "the critical and focal point of [its] defense" to the claims against it was the "alleged misuse" of the equipment; held, the respondent had not "convincingly show[n]" that "a clear, direct conflict existed that could have affected the outcome of the proceeding').

${ }^{124}$ See Airgas, Inc., supra n. 109. Alleging that a law firm had engaged in simultaneous representation of two different clients who were business competitors, the plaintiff filed suit against the firm in Pennsylvania a) for damages, and b) for an injunction retraining it from representing its competitor in a pending Delaware action. The court stayed the entire action, on the understanding that the Delaware Chancery Court would be rendering a decision "promptly" on the motion for disqualification, and that it would provide "a highly desirable alternate forum, served by a capable and experienced judiciary, in matters of complex commercial litigation." Once the issue of disqualification was decided there, the case could then return to the active docket in Pennsylvania----where "in the regular course of the court's business" it could dispose of the request for damages.

${ }_{125}$ See Airbus S.A.S., supra n. 89 ("typically, the challenge to the attorney's qualifications must be made in the forum in which the underlying suit is being litigated," and we have been presented "with no case where an action to disqualify an attorney has been sustained by a court where the relevant litigation has been pending in another tribunal, let alone another country"; the court is "very reluctant to enter the quagmire as to whether its interpretation of the District of Columbia's Code of Professional Conduct ... . should prevail against a ruling by an international tribunal created by treaty"). Cf. Wilkins, supra $\mathrm{n}$. 116 at 808 (the advantages of "locat[ing] enforcement authority inside the institutions in which lawyers work" include the fact that such institutions are in a better "position to observe lawyer misconduct directly").

${ }^{126}$ E.g., UBS PaineWebber Inc. v. Stone, 2002 WL 377664 (E.D. La.)(claimant sought to disqualify counsel in pending arbitration because counsel would be a material witness---or alternatively, sought an 
lacking here the concerns of comity that become salient whenever it is sought to interfere in parallel litigation proceeding in coordinate state tribunals. ${ }^{127}$ But on the other hand, we have the familiar and powerful policies privileging an expedited process of private dispute resolution in accordance with the parties' contractual choice. ${ }^{128}$ To return to our earlier hypothetical, it would seem far too intrusive for a Texas court to dismiss a Texas-admitted attorney from appearing in an arbitration unfolding without incident in Fredonia.

\section{Keeping Our Eyes on the Ball}

55. Unlike the first group of cases with which we started----

- where the necessary inquiry was a familiar one, calling on us to deploy everything that we have learned over the years with respect to the permissible relationships between arbitrators and arbitrants---

- this second group of cases requires us to inquire more deeply into the professional relationship between attorney and client---into the lawyer's duty of loyalty and his obligation to protect client confidences, and into what the client has a right to expect from the representation.

Nevertheless the lodestar is the same, the cabined inquiry that we are called on to make is the same: We ask only, "has counsel's conduct---whether through

order "precluding [counsel] from testifying at the arbitration hearing should he continue" as counsel; held, relief denied; claimant's motion "asks the district court to inject itself into the arbitration proceeding by prospectively restricting the evidence to be proffered at that proceeding"). See also SOC-SMG, Inc. v. Day \& Zimmermann, Inc., 2010 WL 3634204 (Del. Ch.)(there would be "no justification for interfering with the arbitration" "even if [challenged counsel was] a Delaware lawyer, or the arbitration were taking place in Delaware (or both)").

${ }_{127}$ See Airgas, Inc., supra n. 109 at *3 ("public policy concerns implicating federalism and comity attach to the decision to allow a federal court to disqualify Cravath from appearing as counsel for a litigant in a state court proceeding").

${ }^{128}$ Cf. Positive Software Solutions, Inc. v. New Century Mortgage Corp., 619 F.3d 458 ( ${ }^{\text {th }}$ Cir. 2010). In this case the district court had imposed sanctions of $\$ 10,000$ on an attorney for her "conduct during arbitration" (apparently she had "exhibited four particular instances of bad faith during arbitration"); the court of appeals reversed: "The sanctions order threatens unduly to inflate the judiciary's role in arbitration"; by using its power to sanction "the court would, in effect, become a roving commission to supervise a private method of dispute resolution." At the same time, though, the court clerk was directed to send a copy of this opinion to the Office of the General Counsel of the State Bar of Texas"---which I should think would be the appropriate forum in which sanctions should be sought. Compare Legair v. Circuit City Stores, Inc., 2006 WL 278405 (S.D. Ohio)(court held attorney in contempt and ordered him to reimburse opposing party for the "excess attorney's fees" caused by his "dilatory tactics and unprofessional conduct toward the arbitrator and opposing counsel"; note, however, that this did not arise in the context of contractual arbitration but rather of non-binding arbitration---which when ordered by U.S. courts serves merely as a technique to induce settlement). 
- affecting the neutrality of the panel, or through

- 'disturbing the balance of the presentations' by breach of confidence-

tended to 'taint the underlying trial'"? ${ }^{129}$ "Indeed, the current uncertainty over what is 'ethical' underscores ... the wisdom, when considering such issues, of adopting a restrained approach that focuses primarily on preserving the integrity of the trial process." ${ }^{130}$

56. We can profitably unpack this point by beginning with an eminently sensible ICSID decision of 2008: Indeed everything in this paper was already present there in germ.

Fraport AG Frankfurt Airport Services Worldwide v. Republic of the Philippines involved an ICSID annulment proceeding in which the Committee was asked to exclude the claimant's counsel--- who had not appeared in the original arbitration proceeding, but who first appeared on behalf of the claimant seeking annulment-- from "appearing or acting in any way [for claimant] in this arbitration." The allegation was that counsel had earlier been retained by the Manila International Airport Authority ${ }^{131}$ in connection with a "related and still pending ICC arbitration." 132 The disqualification motion was dismissed.

57. It is far from certain that the same result would have been reached through the application of any particular national code of professional ethics. But of course the point---a point that I have been making throughout and will make again---is that this shouldn't particularly matter. Counsel here was a member of the California (as well as of the Paris) bar, and the claimant urged that under the California rules of professional responsibility, there existed an "irrebuttable presumption" that he had acquired confidential information in the course of his representation. ${ }^{133}$ But the tribunal disclaimed having any

\footnotetext{
${ }^{129}$ See text accompanying $n .112$ supra.

${ }^{130}$ Armstrong v. McAlpin, 625 F.2d 433 ( $2^{\text {nd }}$ Cir. 1980)(defendant moved to disqualify law firm based on the participation of one of its partners in litigation against defendant conducted when, before joining the firm, he was with the Securities and Exchange Commission; plaintiff argued that "adequate screening procedures effectively isolated the former government lawyer from those members of his firm handling the matter"; held, disqualification denied; "we do not believe that it is necessary or appropriate for this court to enter fully into the fray" with respect to the proper interpretation of the disciplinary rules; "we need not resolve the ethical propriety of the screening procedure used here ... as long as the district court justifiably regarded it as effective in isolating" counsel from the litigation).

${ }^{131}$ Claimant alleged that the MIAA was merely an "instrumentality of the Republic," but the tribunal did not find it "necessary ... to resolve this question," Fraport $\$ 34$.

${ }^{132}$ The tribunal accepted that there was "substantial overlap" between the subject matters of the ICC and ICSID arbitrations; "both proceedings concern the project for the construction of the Manila Airport Terminal 3, and the actions of the Philippines Government in relation to that project." Id. I 31. ${ }^{133}$ Id. ๆ 29.
} 
"deontological responsibilities": Its only task, it made plain, was to ensure that to the extent there had been any dual representation, this had not impaired "the fair conduct of the proceedings before it." 134

58. So one can describe the tribunal's methodology as follows: One tries to identify---at a very high level of generality---the concerns that animate the challenge, the underlying concerns that might affect the regularity of the proceeding that the tribunal has been hired to conduct. Identifying these concerns then enables the tribunal to assess what is truly "indispensable" to a fair process---and then to allocate appropriately between the disputants where the burden should lie. The actual decision on disqualification, in other words, does not follow from the application of a "rule," but is closely tailored to address the harm that the tribunal is seeking to prevent.

59. Now the Committee did find "valuable" the parties' extensive analyses of the ethical rules of the California and Paris bars---and even took the initiative of asking the parties to brief it on the Code of Conduct for Lawyers issued by the Council of the Bars and Law Societies of the European Union: But this was only for the limited purpose of seeking help in teasing out some "common general principles." A "nice reading" was flatly excluded. ${ }^{135}$ Such an approach is in fact precisely in line with a substantial U.S. jurisprudence, which equally concludes that when faced with a motion to disqualify, even a trial court need not "enter fully into the fray" with respect to the applicability and interpretation of disciplinary rules: ${ }^{136}$ Strictly speaking it may even refuse to consider them. ${ }^{137}$

60. At the same time, of course, it is equally important to fully appreciate what we are not concerned with. This is relatively easy: We are not concerned with cases where counsel conduct fails to present the risk of a significant impact on

\footnotetext{
${ }^{134}$ Id. ๆ 39.

135 Id. ๆף 13, 40-41.

${ }^{136}$ See Armstrong, supra n. 130; see also Enzo Biochem, Inc. v. Applea Corp., 468 F.Supp.2d 359 (D. Conn. 2007)(non-party moved to intervene in litigation for the limited purpose of seeking to disqualify plaintiff's counsel; held, disqualification is not warranted because the counsel's "clients are adverse to each other only insofar as they take opposite positions on a common legal issue in different cases pending in separate trial courts"; although court decisions on disqualification motions may benefit from the "general guidance" provided by the ABA and state disciplinary rules, "courts are not policemen of the legal profession; that is for the disciplinary arm of the bar"). See also ๆTा 47-49 supra.

${ }^{137}$ See Lindgren, supra n. 102 at 457-58 (to ask whether counsel misconduct "tends to taint the trial" is a test that, however vague, "holds the most promise for keeping disqualification within proper boundaries," and, moreover, "is more closely related to the basic function of courts---resolving disputes"; "a court normally need not consider whether the lawyer has breached a disciplinary rule"). In our present context, cf. Branson, supra n. 33 at 622 (the refusal of the tribunal in Hrvatska even to consider whether "English Bar Council Rules" would have allowed counsel to continue to serve while a member of the same chambers remained as President, was "far-reaching").
} 
the proceedings---but where, by contrast, disqualification would instead appear to be nothing but "principled." ${ }^{38}$ We are not, that is, concerned with the "integrity of the legal profession and its high standing in the community," ${ }^{139}$ or with the "ideal role of the lawyer." ${ }^{140}$ Nor with "public confidence in the administration of justice" or the adequacy of litigation as a "law-making process." 141 Nor are we concerned with the expectations generated by an attorney's duty of loyalty ${ }^{142}$---a duty sometimes reframed to embrace the psychology of "attorney-client friendship" ${ }^{143}$ (and thus aimed at promoting "client comfort"144 or a "trusting and harmonious" relationship"145---or conversely, at obviating the possibility that the particular client "might feel betrayed" $"$ or that future clients might become "less candid with or trusting of their lawyers."). ${ }^{147}$ Nor, to round out the list---nor, a fortiori---are we concerned with any resulting "appearance of impropriety"---even assuming that this notion functions as anything more than a surrogate for what was already contained in the previous sentences. ${ }^{148}$ None of that should enter into the equation, despite the fact that a desire to advance all these interests may properly take its place among the policies served by conflict-of-interest rules.

\footnotetext{
${ }^{138}$ Yes, I am using the term pejoratively. Cf. Swisher, supra n. 7 at 50 ("principled" or "punitive" disqualification is "an unnecessary disqualification [in the sense that] the lawyer could continue the representation and the misconduct has been, or could be, completely stopped without resort to disqualification"; it "seems heavy-handed at first blush," although the author ultimately advocates looking at a more "holistic picture").

${ }_{139}$ Int'l Business Machines Corp. v. Levin, 579 F.2d 271, 283 (3d Cir. 1978)(firm's representation of clients "in two entirely unrelated areas"; "disqualification in circumstances such as these where specific injury to the moving party has not been shown is primarily justified as a vindication of the integrity of the bar").

${ }^{140}$ Swisher, supra n. 7 at 61.

${ }^{141} \mathrm{Cf}$. Developments in the Law---Conflicts of Interest in the Legal Profession, 94 HARV. L. REV. 1244, 1478, 1480 (1981)(since even an ordinary case "may make important law," and "the law emanating from the case" may be "transformational," the court "may have the right, and perhaps the duty, to ensure that both sides have the benefit of the strongest possible representation").

${ }_{142} \mathrm{Cf}$. id. at 1297 ("the primary danger is that an attorney who represents adverse interests [even in unrelated matters] may develop a 'sense of loyalty' to one client that will 'undermine' his representation of the other). See also Pfizer, Inc. v. Stryker Corp., 256 F.Supp.2d 224 (S.D.N.Y. 2003)(defendant moved to disqualify plaintiff's counsel, who had also entered appearances on behalf of defendant in two product liability suits; "risks [such as the impairment of the attorney's incentive to act vigorously on behalf of the client] almost always exist when a lawyer sues a current client," but "a rule of per se disqualification would serve only to enforce the attorney's duty of loyalty to the client. It would not protect the integrity and accuracy of the court's decision-making").

${ }_{143}^{14}$ Developments in the Law, supra n. 141 at 1302.

144 GILLERS, supra n. 11 at 135.

145 Developments in the Law, supra n. 141 at 1297-98.

${ }^{146}$ Swisher, supra n. 7 at 58.

147 GILLERS, supra n. 11 at 137.

${ }^{148}$ Swisher, supra n. 7 at 90, 102; cf. Fraport at $\mathbb{} 55$ ("The Committee cannot act in this regard simply on mere appearances since to prevent a party from having access to its chosen counsel . . must flow from clear evidence of prejudice").
} 
61. Now when I say that "none of that should enter into the equation," I certainly do not mean to suggest that an arbitrator may lack the competence or ability to deal with these concerns----whether or not they are presented as the dictates of mandatory law. I earlier asserted in fact that he does not. The suggestion is rather that these matters in the normal course fall outside his usual job description---that this is not what the parties (his principals) have hired him to do. Unlike, say, the antitrust violations at stake in a case like Mitsubishi, to assess the conduct of counsel by interpreting some mandatory code of professional conduct is simply not necessary to resolve the legal dispute between the parties. In the absence of some demonstration that the integrity of the proceeding is in question, the only litigant interest---the only interest intrinsic to the arbitration---that needs to be weighed is the delay and disruption that the exclusion of counsel would cause.

62. The discussion to this point could certainly benefit from somewhat more concrete illustrations of the underlying argument. A complete taxonomy of disqualification cases is hardly feasible here, and in any event well beyond my pay grade. Still, what I have said suggests at a minimum the following: If the "Prime Directive" indeed lies in maintaining the integrity of the proceeding, then we are justified in concluding that disqualification should be denied in recurring cases like these:

a. Where the attorney/client relationship (if there even was one) has not been active or sustained, but on the contrary, insubstantial and peripheral. ${ }^{149}$ This was precisely the case, for example, in Fraport:

${ }^{149}$ See Lindgren, supra n. 102 at 452; Developments in the Law, supra n. 141 at 1330-31.

For some noteworthy examples, see Wyeth, supra n. 18 (law firm that represented defendant in U.S. patent infringement action was also representing plaintiff in an ongoing patent matter in Europe; held, magistrate court erred by applying a rule of "automatic disqualification" and by failing to "weigh the relevant factors"; while an attorney-client relationship did exist between the firm and the plaintiffs so that dual representation constituted a violation of ethical rules, given "the nature and degree of the actual conflict caused by [the firm's] concurrent representation," disqualification was not warranted; the European patent matter "has been dormant" and the firm's lawyers "have billed less than 70 hours in total to the case"); Pfizer, Inc., supra n. 142 (although plaintiff's law firm had entered appearances on behalf of defendant in product liability suits, "plaintiffs and [defendant] are sometimes allied and sometimes adverse in a complex relationship," and the defendant "always has viewed the [law firm,] even when it has appeared in defense of both [parties], as [plaintiff's] attorneys"); Korea Shipping Corp., supra n.112 ("where an attorney has not previously represented an opposing party but has merely communicated with him," any concern that "professional commitment will be endangered" "disappears").

Cf. Silver Chrysler Plymouth, Inc. v. Chrysler Motors Corp., 518 F.2d 751, 756 ( $2^{\text {nd }}$ Cir. 1975)(imputed conflict; attorney employed at plaintiff's law firm had previously been an associate of a firm which did regular work for the defendant, although his work on cases relating to defendant "was limited to informal discussions on procedural matters or research on specific points of law"; held, "there is reason to differentiate for disqualification purposes between lawyers who become heavily involved in the facts of a particular matter and those who enter briefly on the periphery for a limited and specific purpose relating solely to legal questions") 
Challenged counsel had been retained by the Republic, and made counsel of record, in an earlier ICC proceeding, but withdrew shortly thereafter following an allegation of conflict of interest---just three working days had elapsed between the firm's receipt of the ICC file and its suspension of work. "The retainer was still-born." 150

b. Where the attorney may be representing a client and---simultaneously but in a separate and totally unrelated matter---the opposing party.

Dual representation in these circumstances is often taken to be grounds for mandatory and automatic disqualification, since it stems from a clear violation of the rules of professional conduct. ${ }^{151}$ But given the limited brief of an arbitral tribunal, it may well be wondered why this principle should have any purchase here at all. After all, if there is anything at stake in such cases, it is but the extrinsic value of protecting the fiduciary duty of "loyalty" from attorney to client. ${ }^{152}$ And the dynamics of how any sort of challenge here could possibly play out seem exceedingly curious when viewed from the vantage point of

${ }^{150}$ Fraport, ๆ 26, 54.

${ }^{151}$ See ABA Model Rules of Professional Conduct, R. 1.7(a), \& cmt. 6 ("absent consent, a lawyer may not act as an advocate in one matter against a person the lawyer represents in some other matter, even when the matters are wholly unrelated. The client . . . is likely to feel betrayed, and the resulting damage to the client-lawyer relationship is likely to impair the lawyer's ability to represent the client effectively").

GILLERS, supra n. 11 at 139, 142, posits this case: A law firm that represents Sally in some transactional matter is also representing Harry in separate litigation brought by Harry against Sally as a defendant. This, he suggests, "can have a doleful effect on Sally's legitimate interest in being able to work with her lawyer in an atmosphere of trust and confidence"; in addition, Harry "may worry that the firm will not be as aggressive [in his suit because Sally] is a firm client." See also Cinema 5 Ltd. v. Cinerama, Inc., 528 F.2d 1384 ( $2^{\text {nd }}$ Cir. 1976)("When Cinerama retained Mr. Fleischmann as its attorney in the Western District litigation, it was entitled to feel that at least until that litigation was at an end, it had his undivided loyalty as its advocate and champion"; "the lawyer who would sue his own client, asserting in justification the lack of 'substantial relationship' between the litigation and the work he has undertaken to perform for that client, is leaning on a slender reed indeed").

Curiously, the 2010 "Hague Principles on Ethical Standards for Counsel Appearing before International Courts and Tribunals" appear to miss this scenario completely---being content to identify situations where representation is precluded by virtue of a conflict of interest in circumstances where

- counsel seeks to represent "two or more clients in the same proceedings," and where

- counsel seeks to represent "a new client in proceedings where a former client is party to the same or closely related proceedings" [the problem in Fraport].

Study Group of the International Law Association on the Practice and Procedure of International Courts and Tribunals, The Hague Principles on Ethical Standards for Counsel Appearing before International Courts and Tribunals, §§ 4.1, 4.2.

152 Pour le Bébé, supra n. 123 at 453 ("the primary value at stake in cases of simultaneous or dual representation is the attorney's duty---and the client's legitimate expectations---of loyalty, rather than confidentiality"). 
promoting rational dispute resolution. ${ }^{153}$ Even in state courts we frequently come across judges who blink at the consequences of disqualification in such circumstances. ${ }^{154}$

\section{c. It should probably go without saying that}

- mandatory professional rules that are protectionist in nature---such as those regulating the unauthorized practice of law---or

- mandatory professional rules that attempt to monitor the content of the agreements between counsel and client---such as those governing the structure of permissible fee arrangements, or the handling of client funds---

\footnotetext{
${ }^{153}$ See $n$. 151 supra: Assume again that Sally is being sued by Harry, and that the same firm not only represents Harry in this lawsuit, but, at the same time, represents Sally in connection with an unrelated transaction. "A court focusing primarily on the potential for trial taint" would not rationally respond by disqualifying the firm "from the litigation in order to cure ethical problems outside the litigation"; the better response to any complaint by Sally would simply be to "advise her to dismiss the firm in the nonlitigation matter." If however the ethical question should surface in the course of the litigation, it is very hard to understand why Sally "should be heard to object to inadequate representation of its adversary." Developments in the Law, supra n. 141 at 1476-77 (nevertheless concluding, in extremis, that the answer may lie in externalities, in the interest "of the public or of the judiciary"). See also Crystal, supra n. 108 at 11 (if the client "facing the risk of reduced zealousness" in litigation "is willing to waive any objection to the firm's continued representation," why should the other party "be allowed to obtain disqualification of opposing counsel to protect the integrity of the attorney-client relationship of its adversary? This is an odd form of paternalism indeed").

But consider All-Star Carts \& Vehicles, Inc. v. BFI Canada Income Fund, 2010 WL 2243351 (E.D.N.Y.). Here the defendants moved to disqualify a law firm from representing plaintiffs in a putative antitrust class action; the claim of an "impermissible conflict of interest" was based on the fact that the attorney was also "regular counsel" for a non-party witness who was also a major competitor of defendant---a dual representation which supposedly would make the attorney "unable to provide undivided loyalty to each client." Thus the problem: Either the attorney (a) on behalf of the class, "will not aggressively pursue discovery" from the witness; or (b) on behalf of the witness, he "will fail to follow the evidence where it leads because of the possible implication of [the witness] as a participation in the monopolization" of the market. Disqualification was denied---although the rationale seems unduly cautious, and admittedly falls very far short of where I would like to go---that is, falls far short of suggesting that all this should simply be deemed irrelevant: The court was satisfied to note while "there is the possibility" that the attorney "may face a conflict in trying to zealously protect" simultaneously the interests of the class and the witness, "at the present time, such conflict has not been established." ${ }^{154}$ See Swisher, supra n. 7 at 9 ("In the past, disqualification was all but automatic when lawyers sued their current clients"; "in the present," although "the representation clearly violates the ethical rules," "the disqualification remedy might not follow because it depends on the balance of equities in the case"); see also, e.g., Reese, supra n. 112; Pioneer-Standard Electronics, Inc. v. Cap Gemini America, Inc., 2002 WL 553460 (N.D. Ohio)("a rebuttable presumption is established by concurrent representation"; here "there is no reason to believe" that the law firm "could not pursue both the Cap Gemini litigation and the European Commission matter with equal vigor and without using confidential information to the detriment of either client").
} 
should be, to the extent that they have no impact whatever on the conduct or regularity of the proceedings, off-limits as grounds for arbitral disqualification. ${ }^{155}$

63. "a." and "b." above are already important in and of themselves. But they are important also because the particular fact patterns reveal something critical: In such cases, even if a conflicted attorney may have obtained some confidential client information from an adverse party, such information is "likely [to] be of little or no use" in the proceeding. ${ }^{156}$ This raises a broader and more fundamental point: If we are at all concerned about attorney "conflict of interest," after all, it is presumably out of a desire to "protect a former client's confidential information against the risk of revelation or adverse use"---a concern that dual representation may place the conflicted attorney in "at least potentially a position to use privileged information concerning the other side." ${ }^{157}$ This is the engine driving the machine. ${ }^{158}$ Disqualification is not warranted, then, to redress any imbalance between the parties where the risk is slight that dual representation has given one party an unfair advantage by virtue of

- having obtained insights about his opponent, which

${ }^{155}$ See BORN, supra n. 48 at 2312. A particularly powerful illustration is European Community, supra 112 , in which the defendants raised "serious questions" about the retainer agreement between one of the plaintiffs and plaintiff's counsel; features of this agreement, such as "the degree of control to be exercised by the attorneys over the litigation,"' and a contingent fee, were alleged to "offend the ethical rules governing the conduct of attorneys practicing in this district." But this hardly affected the conduct of the trial---it was conceded that the case did not involve any "issues of prior representation or misuse of privileged information." So a motion to disqualify was denied: It was simply not the trial court's role to "remedy any ethical violations," and the "increase in tactical motions' that "zealous trial court intervention" would promote would result in "needless disruption and delay."

${ }^{156}$ See Lindgren, supra n. 102 at 452.

${ }^{157}$ GILLERS, supra n. 11 at 143, European Community, supra n. 113 at 305.

${ }^{158}$ But cf. Steven H. Goldberg, The Former Client's Disqualification Gambit: A Bad Move in Pursuit of an Ethical Anomaly, 72 MINN. L. REV. 227, 273-74 (1987). Professor Goldberg argues that "confidentiality lacks intrinsic value," and that:

The adversary system has no case-specific interest in a client's right to keep confidential information from influencing the outcome of a matter. If the client's confidential information from the first representation affects the result when used in the second ... the adversary system has reached a decision closer to the truth. The client whose confidential information has been used or divulged, although unhappy, has not been deprived of either an accurate or a fair result.

This is, I think, willfully idiosyncratic: Without taking a position on the empirical question of whether current disqualification rules "meaningfully affect the frequency or completeness of client disclosure to lawyers," I believe most of us would conclude that "greater truth" is bought far too dearly, if bought at the price of a radical disruption in a litigant's expectations through the violation of trust placed in a fiduciary. 
- promise to be of use in the current litigation.

If this is our concern, then the whole enterprise reduces itself into a mundane inquiry with respect to

- how to gauge the extent of the risk, and

- who has the burden of demonstrating it.

64. Finding no "taint" in this sense, the Committee in Fraport deployed a methodology of cautious common sense in approaching the ultimate question--whether there existed any "real risk" that challenged counsel had received confidential information "relevant" to the proceedings. ${ }^{159}$

- We know that where one begins is often likely to dictate with some accuracy just where one will end up---and here the bar was selfconsciously set extremely low: The Committee asked, what "general principles are plainly indispensable for the fair conduct of the proceedings?" ${ }^{160}$ This was the critical starting point---and, formulated in that way, naturally foreshadowed the result.

- And then, the Committee's assessment of the facts was aided by some working assumptions with respect to the way attorneys, in its experience, usually function: Thus it was not "inherently improbable that a law firm would agree to go on the record for a government entity" urgently requiring representation, and before it received any confidential information"161 ----or at least the circumstances were "not such as necessarily to require" the opposite conclusion. ${ }^{162}$

- And the Committee's task was made somewhat easier---although the decision does not make much of the fact---that this was after all merely an annulment proceeding; in consequence the scope of the issues, argument and evidence would be considerably more circumscribed than in the principal proceeding on the merits. ${ }^{163}$

\footnotetext{
${ }^{159}$ Fraport 9 45; cf. Silver Chrysler Plymouth, Inc., supra n. 149 at 757 ("to apply the remedy [of disqualification] when there is no realistic chance that confidences were disclosed would go far beyond the purpose of [the Canons of Ethics]").

${ }^{160}$ Fraport 941.

${ }^{161}$ Id. ๆ 51.

162 Id. at 954 . The syntax here and throughout is strikingly convoluted, but my diagnosis is that this reflects nothing more than a temperamental or constitutional desire to eschew overstatement, and not any substantive embarrassment.

${ }^{163}$ Challenged counsel had only appeared for the first time in the annulment proceeding; but see id. at $\uparrow$ 35 ("the grounds for any request for annulment must relate to the conduct of the Tribunal").
} 


\section{That}

- this is not "discipline," and that

- an arbitrator is in any event not charged with the social duties and responsibilities of a state court,

make it overdetermined that the "black letter"---let alone the "niceties"---of any mandatory rule must be put aside; it will remain secondary to the tribunal's sole mandate, which is to ensure that a party has not in fact been prejudiced to such an extent as to impair the integrity of the proceedings. ${ }^{164}$ To illustrate briefly:

66. A state's mandatory "rule" may be stated in terms something like this: that a disqualifying conflict is present where counsel has previously represented a client in a matter which is "the same as or substantially related to" the matter in which he now seeks to represent an adverse party. ${ }^{165}$ Like most verbal formulations, this hardly advances the ball very far---and it is in fact less helpful than most: For it seems generally understood that any talk about a "substantial relationship" is just a convenient surrogate for what really matters, and what we already knew was critical all along---it is defined functionally in terms of

- the extent of the risk that confidential information may have been disclosed, and

- the extent of the risk that it may be used adversely to the former client in the current proceeding. ${ }^{166}$

\footnotetext{
${ }^{164}$ For example, if we are concerned only about prejudice, there would seem to be no room, under any circumstances, for the application of any paternalistic rule under which counsel conflict remains impermissible even when it has been consented to; cf. Laurel Terry, An Introduction to the European Community's Legal Ethics Code, in MARY C. DALY \& ROGER J. GOEBEL (EDS.), RIGHTS, LIABILITY, AND ETHICS IN INTERNATIONAL LEGAL PRACTICE (2ND ed. 2004) at 221, 251-2.

Putting aside the "niceties" of national rules---focusing on the essential core---and thus setting the bar so low, should minimize the concerns expressed by Professor Rogers, who argues that a tribunal forced by a disqualification motion to "choose" between "U.S. ethical standards"---under which certain conflicts of interest would be deemed "prima facie impermissible"--- and European standards, would be likely either way to "disappoint the expectations of one of the parties." Catherine A. Rogers, Fit and Function in Legal Ethics: Developing a Code of Conduct for International Arbitration, 23 MICH. J. INT'L L. 341,378 fn. 181 (2002).

165 See, e.g., ABA Model Rules of Professional Conduct, Rule 1.9(a). To revert to an earlier example, counsel may seek to represent Harry in his suit against Sally--- but may previously have represented Sally in a "substantially related matter," causing Sally to move for his disqualification.

${ }^{166}$ See, e.g., GILLERS, supra n. 11 at 179 (the "substantial relationship test" is "an effort to identify those adverse matters in which the former client's confidential information will be at risk"); Talecris Biotherapeutics, Inc., supra n. 102 ("when performing the substantial relationship analysis," one factor is
} 
Indeed, it is apparently the case that if information has been obtained in a prior representation, but has "been rendered obsolete by the passage of time," the two matters will be deemed not "related." 167 This speaks volumes--because it draws our attention to the fact that although precisely the same legal issues may have been involved at all times---the "cause of action" being identical ${ }^{168}$---the risk of prejudice has dissipated. That's all we need to be aware of. And there is always abundant play in the joints: In general the notion of a "relationship" can be

- expanded or contracted depending on the tribunal's assessment of the apparent risk in the particular case. (We can, of course, gradually develop some reasonable rules of thumb: One is that it would be overinclusive and indeed draconian to sweep ordinary business practices into this notion of endangered "confidential information"---promoting disqualification when the only risk has been the disclosure of such matters as the client's "long-term objectives and competitive strategies," ${ }^{169}$ or its "policies or past practices,"170 or its "litigation philosophy" or "legal and organizational structure"). ${ }^{171}$

\footnotetext{
"the possibility that the client disclosed confidences to his attorney which could be relevant to the current action"; held, disqualification denied; "there is no doubt that the two litigations overlap to some degree," but "any confidential information [counsel] may have learned about the Tenoid patent during its brief representation of [the co-defendant] is not relevant to the validity of [the patent being challenged]"); Analytica, Inc. v. NPD Research, Inc., 708 F.2d 1263 (7 $7^{\text {th }}$ Cir. 1983)(Posner, J.)("substantially related" "means, if the lawyer could have obtained confidential information in the first representation that would have been relevant in the second," although "it is irrelevant whether he actually obtained such information and used it against his former client"); here counsel "not only had access to but received confidential financial and operating data of NPD" when putting together a deal to transfer stock to an employee; this data "concerned NPD's profitability, sales prospects, and general market strength----all matters potentially germane to both the liability and damage phases of an antitrust suit charging NPD with monopolization. The two representations are thus substantially related").

A very different approach indeed is represented by In re American Airlines, Inc., supra n. 116, which suggests that we should instead go about things precisely "the other way around": It is not the case, the Fifth Circuit asserts, that a "substantial relationship" is established by demonstrating "a genuine threat" that confidences revealed to a former counsel will be divulged to his present adversary; rather, this "genuine threat" "is established by [first] showing that a prior representation is substantially related to the present case." $972 \mathrm{~F} .2 \mathrm{~d}$ at 615 . The problem is that the former method requires a functional analysis that focuses on an identified danger, and the latter is little more than verbal. See id. at 619, 625-26 (the "two representations need only involve the same 'subject matter' to be substantially related," and here disqualification would be ordered even if it could be shown "that all of the information provided by [the former client] was public knowledge").

${ }_{167}^{167}$ ABA Model Rules of Professional Conduct, Rule 1.9(a) cmt. 3.

${ }^{168} \mathrm{Cf}$. WOLFRAM, supra n. 14 at 370.

169 Mauritrans GP Inc., supra n. 103 at 1280.

${ }_{170}^{170}$ Glueck v. Jonathan Logan, Inc., 653 F.2d 746, 750 (2 ${ }^{\text {nd }}$ Cir. 1981).

171 Pour le Bébé, supra n. 123 at 455. See also JANINE GRIFFITHS-BAKER, SERVING TWO MASTERS: CONFLICTS OF INTEREST IN THE MODERN LAW FIRM 128 (2002)("we . . . know all about their ... partnership affairs and how they approach a case in terms of settling it").
} 
- And weighed against other process considerations that go to the fairness of proceeding---weighing it, for example, against the lack of diligence of the objecting party, and the hardship to the client and disruption to the trial process that would ensue if replacement counsel has to be found and briefed. ${ }^{172}$

\section{Once the}

- perceived risk of prejudice from the use of "confidential information" has led

- to a finding of a "substantial relationship" between the current and prior representations, then

- regulatory rules of national law may sometimes irrebuttably presume that counsel has received such information. ${ }^{173}$

Despite appearances this is not entirely tautological; ${ }^{174}$ the movement from mere risk, to conclusive presumption, is often alleged to serve a prophylactic function. ${ }^{175}$

This may perhaps be barely justified if counsel's acquaintance with the former client's "playbook" has been long-standing and intensive. [See, e.g, Frazoni v. Hart Schaffner Marx, 726 N.E.2d 719 (III. App. 2000)(retaliatory discharge action; plaintiff's counsel had previously served as general counsel to the defendant's parent company and had handled hundreds of employment-related discrimination matters, "evaluating claims and advising and consulting with management concerning litigation strategies and settlement options"); Ullrich v. Hearst Corp., 809 F.Supp. 229 (S.D.N.Y. 1992)("for nearly 20 years [counsel] has been rendering legal advice and litigation services to [defendant] in matters that are very closely related to issues arising in these three lawsuits"; his "negotiation of severance packages and settlements on behalf of [defendant] in cases of other employees raising similar claims gives him unquestionable confidential information as to how [defendant's] management assesses its vulnerability on such claims"]. But the consequences of disqualification arising out of isolated representation in otherwise unrelated matters would be draconian indeed. See generally ABA Model Rules of Professional Conduct, Rule 1.9(a) cmt. 3, which distinguishes for this purpose between "general knowledge of the client's policies and practices" and "knowledge of specific facts."

172 See generally Swisher, n. 7 at 22-23, 43, 86.

${ }^{173}$ E.g., Marketti v. Fitzsimmons, 373 F. Supp. 637 (W.D. Wisc. 1974)(representation of "an interest adverse to a former client" "would seem a breach of trust to the lay sense of justice," and "proof that no confidential information had been disclosed during the prior representation would not remove the taint of disloyalty"); Engineered Prods. Co. v. Donaldson Co., Inc., 290 F.Supp.2d 974, 983, 985 (N.D. lowa 2003)(non-rebuttable presumption that "during the course of the former representation confidences were disclosed to the attorney bearing on the subject matter of the representation"); see generally WOLFRAM, supra n. 14 at 369; Developments in the Law, supra n. 141 at 1328-33.

${ }^{174}$ Cf. GILLERS, supra n. 11 at 179 ("in deciding whether two matters are substantially related, a judge will ask whether ... a lawyer will have acquired confidences that can be used to harm the former client in the new matter"; but then, what is the "substantial relationship" test after all, other than merely a 
68. Such a rule, as we have seen, was argued to the Committee in Fraport. ${ }^{176}$ But given the limited nature of the representation, any claim that the receipt of confidential information should be "presumed" was dismissed as simply "not compelling." 177 It would have been enough under the actual circumstances simply to decline to be bound by such a rigid "presumption"---although it would seem more satisfactory still to find any "presumptions" of any sort essentially irrelevant.

It would be wielding a meat cleaver rather than a scalpel to exclude counsel on the basis of a conclusive "presumption" once the tribunal was convinced that the risks of the actual adverse use of client information, in ways relevant to the dispute, were in any event small---and in fact trivial when weighed against the consequences to the proceeding. Such a presumption is hardly necessary for the effective protection of client confidences---nor, by the same token, is it necessary in the crafting of a workable arbitral rule of thumb. ${ }^{178}$ Once again the Devil is found lurking in the details.

69. A strong presumption that counsel has received "confidential information" is often justified by the assertion that requiring a former client to provide proof of disclosure would mean that the "confidentiality of the information would be lost in the very process of attempting to protect it."179 But of course, a presumption of any sort---let alone one that is "irrebuttable"---is less justifiable where a party who seeks disqualification is permitted to make relevant submissions to the tribunal in camera. ${ }^{180}$

\footnotetext{
"shorthand way of saying that when that kind of relationship between two matters is established ... we presume that the former matter will have given the lawyer confidential information relevant to the new matter"?).

${ }^{175}$ E.g., Tekni-Plex, Inc. v. Meyner \& Landis, 674 N.E.2d 663, 667 (N.Y. 1996)(mandating disqualification "irrespective of any actual detriment" prevents "even the possibility that [a client's "secrets and confidences"] will subsequently be used against the client in related litigation").

${ }^{176}$ See $\lceil 57$ supra.

177 Fraport \ 52.

${ }^{178}$ See, e.g., HUGH EVANS, LAWYERS' LIABILITIES 72-78 (1996)(English and Canadian law; "directly the existence or possible existence of any such danger is negatived, the whole basis and substructure of the possibility of injunction is gone").

${ }^{179}$ WOLFRAM, supra n. 14 at 369; Developments in the Law, supra n. 141 at 1329 ("by forcing a client to prove receipt of information, the cloak of secrecy would be torn from the attorney-client communications"); United States Football League v. Nat'I Football League, 605 F.Supp. 1448, 1461 (S.D.N.Y. 1985)(“a direct inquiry into whether confidential information was in fact transmitted by the client ... would be improper; it would put the movant to the choice of either revealing its confidences in order to prevail on the motion or else refraining from moving to disqualify, thereby running the risk that its adversary will use its confidences against it in the litigation").

${ }^{180}$ See Decora, Inc. v. DW Wallcovering, 901 F.Supp. 161 (S.D.N.Y. 1995)(ex parte in camera submissions are acceptable not only "to rebut the presumption that an attorney who worked on a substantially-related matter for a former client actually obtained confidential information," but also "where testimony or documents are offered to establish the existence of a substantial relationship in the first instance"; "while a court is permitted to consider ex parte submissions in determining whether the
} 
70. If the extent of the risk is the ultimate question, this should leave allocation of the initial burden of going forward---always an essential tool of judicious case management---open for discussion. In Fraport the tribunal had "invited" the challenging party to "clarify whether it contends" that counsel had ever received confidential information from the Republic---which of course was precisely the appropriate inquiry. In response there was apparently the predictable and tendentious submission of a report from an "expert," "opining" that confidential information "definitely was shared" because counsel must have been informed of the Republic's "objectives [and] reasons for hiring him"--but that was all; the tribunal noted that there was no allegation that counsel had "received specific confidential information"---something that counsel himself had formally denied. ${ }^{181}$

71. In addition, whatever the initial strength of a "presumption," the rule must invariably bend---rebuttal will be routinely permitted---in cases where the "conflict of interest" is merely imputed. This is true in particular in the common situation where an attorney who has "migrated" to another firm is permitted to cleanse himself, or his new firm, from any infection arising out of the prior representation. ${ }^{182}$ Nevertheless the bluff refusal in the first place by the

presumption that confidences were conveyed has been rebutted, it would defy reason to prohibit such submissions in determining whether confidences were actually conveyed in the first place"); United States Football League, supra n. 179 at 1462 ("at the request of plaintiffs (the movants herein), and with defendants' consent, I have issued a confidentiality order directing that all submissions to the Court for purposes of this motion be filed under seal. This has enabled the parties to reveal to me in camera the full scope of the attorney-client relationship"; "to hold the presumption irrebuttable in a case like this one simply makes no logical sense"). See also Swisher, supra n. 7 at 106 (courts "should generally grant both requests to submit materials for in camera review, particularly when another judge can or will preside over the trial, and requests to seal the proceedings").

${ }^{181}$ Fraport ๆ $13,47,49$.

On the accordion-like nature of the whole notion of "confidential information," see also 966 supra. ${ }^{182}$ Thus counsel who would be deemed to be "conflicted" only vicariously---that is, simply by virtue of being employed at a firm---will be permitted to prove, after joining another firm, that he is not in possession of any confidential information from the prior representation; see Model Rules of Professional Conduct R. 1.09, cmts. 5, 6 ("Lawyers Moving Between Firms"; where a lawyer has access to the files "of only a limited number of clients and participate[s] in discussions of the affairs of no other clients," then, "in the absence of information to the contrary, it should be inferred that [he] is privy to information about the clients actually served but not those of other clients," and "in such an inquiry, the burden of proof should rest upon the firm whose disqualification is sought"); Freeman v. Chicago Musical Instrument Co., 689 F.2d 715, 723 ( $7^{\text {th }}$ Cir. 1982)("if an attorney can clearly and effectively show that he had no knowledge of the confidences and secrets of the client, disqualification [of the second firm, and presumably of the lawyer himself] is unnecessary"; a court may "rely on any of a number of factors, among them being the size of the law firm, the area of specialization of the attorney, the attorney's position in the firm, and the demeanor and credibility of witnesses at the evidentiary hearing.").

Even where this is not possible---that is, where counsel would instead be deemed "conflicted" because of actual protected knowledge obtained during a prior representation---his new firm may be able, whether by an appropriate "screening" mechanism or otherwise, to rebut any presumption that the 
tribunal in Fraport even to entertain presumptions of any sort, brings with it real advantages---among other things relieving a tribunal of the need to track and master the infinite intricacies and complexities, within and between jurisdictions, of this area of the law. Fraport was not only on its facts an easy case, but more fundamentally, a textbook example of how to proceed.

\section{Transnational Rules}

72. A recurrent theme here, foreshadowed at the very outset, is this: To the extent our prime concern is what happens in the course of the proceeding itself, then the content of any "ethical rule" doesn't seem to matter much: At the very least (this is admittedly a weaker claim), there would appear to be no reason why results should be congruent with what is dictated by any national code. We are aiming here at something quite different. This would suggest, then, that at least with respect to the problem this paper has been concerned with, the dangers posed by the uncertain applicability of differing or inconsistent "national ethical codes"---the danger of international arbitration "dwelling in an ethical no-man's land"---are easily exaggerated. ${ }^{183}$

73. This would also suggest that true ethical or moral imperatives---emanating perhaps from our undoubtedly rich interior lives---equally do not come into play. As I wrote several years ago, since we are "merely searching for the rules of the game," it may not be an overstatement to say that "ethical questions are likely to resolve themselves at bottom into issues of contract interpretation---strongly leavened with considerations of prudence." ${ }^{.184} \mathrm{By}$

confidences have been shared with other members of the firm. See Swisher, supra n. 7 at 38 ("but only in certain jurisdictions"; "this type of lateral screening is both in legal flux and highly controversial"); Restatement of the Law Third, The Law Governing Lawyers $\S 124 \mathrm{cmt}$. $d$ (2000)(permitting screening "in situations in which the information possessed by a personally prohibited lawyer is not likely to be significant"; "the lawyer or firm seeking to remove imputation has the burden of persuasion that there is no substantial risk that confidential information of the former client will be used with material adverse effect on the former client"). Cf. Carbo Ceramics, Inc. v. Norton-Alcoa Proppants, 155 F.R.D. 158 (N.D. Tex. 1994)(associate had billed over 200 hours working on the case while employed by plaintiff's counsel and later joined the firm representing defendant; held, motion to disqualify defendant's counsel denied; the associate was employed by the challenged firm for only two months; he was "Chinese-walled" when there, and numerous affidavits from people at the firm stated that he "had "never conveyed or received any confidential or privileged information with regard to this action"; "under the circumstances an irrebuttable presumption of imputed knowledge is unduly harsh!")(italics and exclamation mark in original).

${ }^{183}$ Cf. Rogers, supra n. 164 at 342 ("the extraterritorial effect of national ethical codes is usually murky, as is the application of national ethical rules in a nonjudicial forum such as arbitration").

${ }_{184}$ Alan Scott Rau, On Integrity in Private Judging, 14 ARB. INT'L 115, 155 (1998)(“losing sight of the fact that we are merely searching for the 'rules of the game' is what so often makes discussions of 'ethics' in 
"contract interpretation," I mean simply that an arbitral tribunal would be asked to inquire into what it is that contracting parties have the right to expect of each other---and then to assess their conduct not only with respect to the substantive duties of the underlying transaction, but also with respect to the dispute resolution procedure that they agreed to. (These are but two sides of the same contractual coin.). Anything more is just salesmanship. ${ }^{185}$

74. In any event the inadequacies of a conflict-of-law approach striving to identify appropriate national rules of professional ethics are well known: For reasons that are abundantly familiar, neither the "rules" of the place where a lawyer is licensed, nor the "rules" of the arbitral seat, are likely to present a plausible claim to be applied in international arbitral proceedings. ${ }^{86}$ Viewed from the perspective of a seat of convenience, the state's regulatory interest with respect to the conduct of a transitory lawyer will commonly be exceedingly trivial; in addition, of course, determining the outer limits of counsel's permissible conduct is a question well beyond the scope of the issues that either party, past or current client, is likely to have taken into account in the contractual choice of the lex arbitri. ${ }^{187}$

the professions so sterile---as if this were somehow a matter of morality rather than of economic regulation").

${ }^{185}$ As should be obvious, then, I am not likely to believe that the case for monitoring counsel conduct rests on any desire to promote "moral virtue," or indeed any universal principle at all other than of the most sordid utilitarian sort. See id.; cf. Doak Bishop \& Margrete Stevens, The Compelling Need for a Code of Ethics in International Arbitration: Transparency, Integrity and Legitimacy, in ARBITRATION ADVOCACY IN CHANGING TIMES 391, 392 (ICCA $20^{\text {TH }}$ CONGRESS 2010). Nor am I likely to have a great deal of sympathy with concerns often expressed with respect to the "privatization" of "ethical rulemaking and professional discipline" in international arbitration. Cf. Rogers, supra n. 1 at 41-42 (since "the concept of ethics is steeped in moral and normative symbolism," "many would claim" that ethical rules, as distinct from contract rules, are "by their nature . . . unalterable" and "immutable"). Professor Rogers does conclude, however, that professional rules should nevertheless be treated as "contractually modifiable default rules," with---of course in this respect just like any other contract---external constraints in the form of judicial review for the presence of "consent" and "basic notions of fairness."

${ }^{186}$ See the discussion in BORN, supra n. 48 at 2317-20 ("neither of these two analyses is attractive").

187 See id. at 2318-19 ("the local rules of professional conduct for domestic litigation are usually no better suited for international arbitrations than local rules of civil procedure"; in addition, counsel in international arbitrations usually "have little conception of the local rules of professional conduct applicable [at the arbitral seat] (and less conception that these might regulate their conduct").

These are the reasons why Rule 8.5 of the ABA's Model Rules of Professional Conduct---if taken at face value---is so unsatisfactory. Under this conflict-of-law rule a U.S. jurisdiction, in the exercise of its disciplinary authority, is told to judge litigation-related conduct according to "the rules of the jurisdiction in which the tribunal sits" ["unless the rules of the tribunal provide otherwise"]. The purpose is to ensure that counsel conduct is "subject to only one set of rules of professional conduct"---here, by recognizing the "appropriate regulatory interests of relevant jurisdictions." R. 8.5(b)(1) \& cmt. 3. It is hard to know what to make of this in the context of international arbitration, and in particular, hard to understand why deference is warranted to a place that may lack the slightest connection to the parties or the transaction---but which has been chosen by virtue of an arbitration-friendly legal regime. Nor, by the way, can it be intended that a U.S. client is to be denied any redress against an American attorney, whether in litigation or in a disciplinary proceeding, where the standards of the "seat" happen to be somewhat more lenient. For the 
For that matter, the preceding sentence does not even take into account the struggle that is likely to exist in many jurisdictions between

- the notional or aspirational "law on the books,"

- the operative meaning that the local courts and bar attribute to it, and then,

- the way life is carried on in practice. ${ }^{188}$

Any national standard of professional responsibility will then map very badly on to the work of privately-designed tribunals and privately-chosen decisionmakers.

75. That leaves, then, the possibility of elaborating some independent and transnational standard intended to serve as a placeholder for the various competing alternatives. These may be designed to capture those "common general principles" taken as a lodestar by the Committee in Fraport ${ }^{189}$---the

difficulties in applying R. 8.5, see generally Catherine A. Rogers, Lawyers Without Borders, 30 U. PA. J. INT'L L. 1035 (2009)("there is an emerging realization . . . of the inadequacy of national rules, which were designed to apply to domestic practices in domestic procedural contexts, in regulating global advocacy").

Of course the law of the seat will remain relevant to the question of the finality of the award---that is, to the question whether an award rendered against a party who has been denied his counsel of choice, or by contrast an award procured by noncompliant counsel, can be deemed legitimate under the law applicable to the arbitral proceeding itself. Cf. n. 123 supra.

By contrast, I confess that I am simply unable to grasp the argument advanced in John J. Jacobus \& al., "Conflicts of Interest Affecting Counsel in International Arbitrations," 20:8 MEALEY'S INT'L ARB. REP. (Aug. 2005), to the effect that it is desirable to "apply the arbitration law of the situs as the default standard for attorney disqualification." The "arbitration law of the situs" will invariably have nothing whatever to say about attorney disqualification. Of course the seat can be expected to have rules of professional responsibility that govern the conduct of local counsel, but these are highly unlikely to give rise to vacatur, and, despite the "well-established principle that arbitrations are governed by" the law of the seat, even less likely to "comport with the parties' expectations." The authors boast that their proposal "presents a solution far more simplistic [sic] than other alternatives," and I can at least agree with this characterization without seeing the result as particularly advantageous.

Life is an immobile, locked

Three-handed struggle between

Your wants, the world's for you, and (worse)

The unbeatable slow machine

That brings what you'll get.

"The Life with a Hole in it," PHILIP LARKIN, COLLECTED POEMS 202 (1988).

Somewhat more to the point, perhaps, see GRIFFITHS-BAKER, supra n. 171 at 93 (although "the regulations [with respect to conflicts of interest] adopted by the UK Law Society are considerably stricter than those laid down by its counterparts in other jurisdictions," "firms do not abide by them"), 124, 131 (particularly with regard to large City firms, "the Law Society rules bear no relationship to daily practice"), 174 ("the way in which many solicitors cope with the increasing number of conflicts is, in effect, by breaching Law Society rules").

${ }^{189}$ Fraport 9 41. See also the WTO panel decision in European Communities, discussed at n. 89 supra. 
"core concepts" and "grounds" that are "common" to the various contingent national formulations ${ }^{190}$---the "internationally accepted standards of fairness and justice" ${ }^{191}$ aimed at ensuring the basic fundamental features of an unbiased tribunal and equality between the parties.

76. Such attempts at a "transnational standard" will inevitably and with some justice be deprecated as minimalist lawmaking---that is, "lawmaking" content only to set out what amounts to a lowest common denominator. ${ }^{192}$ What I think is more or less the same point, though, could perhaps be made with a slightly different frame and a slightly more positive spin. Alternatives are available; try this: Given that international practice is marked by such diversity and inconsistent expectations, would it not be fairer to restrict arbitral intervention to cases where the risk of surprise or interference with private autonomy is minimized---in other words, to "limit the range of prohibition" to "conduct which is universally deemed to be reprehensible"? ${ }^{193}$

This, as we have seen, is more or less the approach taken in the sparse and ad hoc arbitral jurisprudence that we now have. But such improvised decisionmaking by hit-and-run arbitrators may appear insufficiently transparent or predictable---or what is worse, insufficiently theorized; to supplement it, an interesting start has already been made in the drafting of proposed "codes of ethics" that are designed to serve precisely the same function. ${ }^{194}$

77. Now all of this is perfectly natural and unexceptional.

a. For one thing, a standard that is intended to be applied in a variety of transnational settings can only find acceptance if it is consciously

${ }^{190}$ See Bishop \& Stevens, supra n. 185 at 397.

191 Jacobus et al., supra n. 187.

192 See, e.g., KATHERINE LYNCH, THE FORCES OF ECONOMIC GLOBALIZATION: CHALLENGES

TO THE REGIME OF INTERNATIONAL COMMERCIAL ARBITRATION 223 (2003)(referring in particular to the UNCITRAL Model Law, "necessarily a compromise" to "ensure acceptance in states with widely differing legal and political systems"; " the process of negotiation and compromise may result in the minimum acceptable standards of normative provision which may be devoid of any precise meaning and which are capable of multiple interpretations"); Gabrielle Kaufmann-Kohler, Soft Law in International Arbitration: Codification and Normativity, [2010] J. INT'L DISPUTE SETTLEMENT 1, 8 (IBA Guidelines on Conflict of Interest; "the working group collected reports on national standards of impartiality for arbitrators [and] then extracted their common features and codified them as general principles").

${ }_{193}$ See Jan Paulsson, Standards of Conduct for Counsel in International Arbitration, 3 AMER. REV. INT'L ARB. 214, 222 (1992); see also Thomas, supra n. 53 at 586 ("conduct that clearly prejudices the fairness of the proceedings").

${ }^{194}$ While the new IBA "Guidelines" are addressed to both counsel and the arbitral tribunal and attempt to establish guidelines for the relations between them, other proposed drafts sweep far more broadly---in purporting to be true "ethical codes" laying down certain principles to govern the relations between counsel and their clients throughout the course of the representation; e.g., "International Code of Ethics for Lawyers Practicing Before International Arbitral Tribunals," in Bishop \& Stevens, supra n. 185 at 408. 
abstracted from local legal cultures---if it refuses to make the difficult choices between them. ${ }^{195}$ Working to that end necessarily entails, for example, putting aside the elaborate exercises in excessive nuance characteristic of the common law. ${ }^{196}$

b. Inevitably, such a restricted mandate will also be closely congruent with the neo-liberal agenda that privileges arbitral autonomy---the critical feature of the institution that has made it so attractive to corporate users. This is equally natural and unexceptional: Indeed to a large extent it's the whole point of the exercise, isn't it?

Now "rules" developed and enforced by arbitrators or arbitral institutions naturally cannot give assurance to an attorney that he will be "relieved" from any sanctions that state courts or professional associations---should they wish to extend their jurisdiction to do so---might wish to impose for a violation of mandatory law. ${ }^{197}$ So while in a sense it can fairly be said that

${ }^{195}$ We are all familiar with the many ways in which questions of professional ethics, when they arise, can demonstrate discontinuity between legal cultures; see, e.g., Margaret Moses, Ethics in International Arbitration: Traps for the Unwary, 10 LOY. U. CHI. INT'L L. REV. 73, 74-75 (2012)(areas where "different legal and cultural backgrounds cause clashes in ethical rules"); BORN, supra n. 48 at 2308-2317 ("areas of particular sensitivity in counsel's professional conduct in international arbitral proceedings").

${ }^{196}$ For example, with respect to the conflicts problems we have been dealing with here, one "code of ethics" that has recently been put forward proposes simply that

- "Lawyers should never represent conflicting interests in an arbitral proceeding without the prior informed consent of the client," and that

- "A lawyer may never use confidential information of a client . . . against that client . . . in subsequent arbitral proceedings."

Bishop \& Stevens, supra n. 185 at 414 (Rule 13).

I'm not at all sure that a ban on representing "conflicting interests in an arbitral proceeding" should naturally be read to encompass the representation, in one arbitral proceeding, of interests that happen to be adverse to those of a previous (non-current) client arising out of a discrete prior representation----the problem in Fraport---although the comments do suggest otherwise. In the second sentence, to bar the "use" of confidential information seems to suggest that such prohibited "use" would have to be affirmatively demonstrated, with the result that a prophylactic rule arising out of the mere risk of disclosure must be put aside. In this and other respects the proposed code hardly goes as far as U.S. law---although U.S. conflicts rules, it has been said, "are among the strictest in the world," John Toulmin, A Worldwide Common Code of Professional Ethics?, 15 FORDHAM INT'L L.J. 673, 681 (1992). Nor, I would think, does it go as far as French law; cf. ADER \& DAMIEN, supra n. 15 at 340 (under the decree of July 12, 2005, a lawyer may not represent a new client if there is a "risk" that the confidentiality of information revealed by a former client may be violated, or if a lawyer's knowledge of the former client's "business" [affaires] would prove "advantageous to" [favoriserait] the new client).

${ }^{197}$ See BORN, supra n. 48 at 2318.

Cf. Kirsten Weisenberger, Peace is Not the Absence of Conflict: A Response to Professor Rogers's Article, "Fit and Function in Legal Ethics," 25 WIS. INT'L L.J. 89, 117 (2007), who writes that "ethical rules that are promulgated and enforced by the arbitral tribunals themselves" would "displace sovereign regulation of lawyers' conduct with a private regime under the sole authority of the arbitral tribunals." This is wrong on the positive law but accurately captures the spirit emanating from such proposals. 
such rules "simply add another set of rules to existing ones," 198 they may nevertheless, as a practical matter, provide a "safe haven" for conduct taking place before the arbitral tribunal---which is after all the only forum likely as a practical matter to concern itself with the problem. And with respect to the wider world outside, they may perform the public-relations function of helping to maintain "public confidence" in the integrity of the international arbitral system---thereby lending it "credibility" and "legitimacy."199

This legitimacy interest might be thought most important in maintaining the acceptability of the arbitral process to customers in the marketplace---but other engines help drive the machine as well:

There is, for example, the desire to forestall officious meddling by adventuresome state courts. This would not be the first time (nor will it be the last) that the "epistemic community" ${ }^{200}$ of arbitrati will have tried to leverage its prestige to mesmerize, or overawe, or bully, national courts into keeping their hands off the institution of international arbitration. ${ }^{201}$ The rhetoric of "self-regulation" is thus harnessed to the wider agenda of delocalization, aimed at ensuring that any dependence of the arbitral system on local state tribunals remains attenuated. (Once again, if one wishes, alternative and more attractive formulations are undoubtedly available---they may make much the same point, and in the service of much the same agenda, but far more benignly). ${ }^{202}$

\footnotetext{
${ }^{198}$ Schneider, supra n. 3 at 499.

199 See Bishop, supra n. 1 at 388, Bishop \& Stevens, supra n. 185 at 407.

200 See LYNCH, supra n. 192 at 94-97 ("shar[ing] a set of normative and principled beliefs . . . in an ideal of international private justice---that is, a belief in the legitimacy of private dispute resolution through arbitration"); see also JOSHUA KARTON, THE CULTURE OF INTERNATIONAL ARBITRATION AND THE EVOLUTION OF CONTRACT LAW 21-24 (2013)(international arbitration practitioners "constitute a network"; they "tend to share similar epistemic conceptions of an ideal of international private justice").

201 The locus classicus is YVES DEZALAY \& BRYANT G. GARTH, DEALING IN VIRTUE:

INTERNATIONAL COMMERCIAL ARBITRATION AND THE CONSTRUCTION OF A TRANSNATIONAL LEGAL ORDER 156-61 (1996)(calling attention to the "symbolic value" of the ICC's brief in Mitsubishi; painting "an elite image of private justice," the "essence of the ICC argument was, "look at who we are"'). More recent examples will readily spring to mind.

202 The classic move---abundantly familiar from the lex mercatoria literature---is to invoke, in matters of international trade, the need to "adapt" (or "temper," or "dilute") obsolete and---the ultimate pejorative--"parochial" views still found in domestic law to the expectations of the wider merchant community. Cf. Paulsson, supra n. 193 at 218-19, 221-22 (it is a commonplace that the "international character" of an arbitration may lead to the toleration of conduct prohibited under mandatory domestic law, subject to some safety valve of international public policy; the lesson here is that national legal systems must "adapt their restrictions on professional conduct to international usages"---“adapting them, in a necessary spirit of tolerance and compromise, to the expectations of an increasingly interdependent global community"---so that local lawyers will not be "penalized" by comparison to their counterparts abroad).
} 
c. And finally, we return here to our main theme: Precisely because of their regulatory spareness, transnational rules will have the virtue of directing the attention of arbitral tribunals to the core of what alone is critical---that is, to what is minimally necessary to ensure the fairness of the proceedings. "Guidelines" or "institutional rules"---as well as arbitral precedent---thus become codifications of the essential expectations of the parties on this subject. If this is the only function that a jurisprudence of disqualification will perform, it should be enough. The direction of arbitral incentives is always highly fraught, and I will not take even a single step towards speculation on this subject---other than to note that a delayed or disrupted or abortive proceeding, and a tainted proceeding, can both reflect equally badly on the reputation of an arbitrator. ${ }^{203}$ But making the tradeoff, each case in a fact- intensive manner, is something that the tribunal in charge of the process must work out for itself.

${ }^{203}$ Cf. Rogers, supra n. 1 at 26, who focuses on the incentives of arbitral institutions---and who argues in this connection that their "direct financial interest in attracting parties," and "increasing competition" among them, give them a "strong incentive to select rules that will ensure the integrity of the arbitrations" conducted under their auspices. Perhaps---but does it really follow that in assessing the reputation of individual arbitrators, users do not equally, at the same time, have an interest in "seek[ing] to have the least limiting ethical constraints imposed on their counsel"? (a question to which their ultimate position as claimant or respondent would appear to be irrelevant; cf. id. at fn. 130). 